\title{
Demography and the Palaeolithic archaeological record
}

\author{
Jennifer C. French
}

McDonald Institute for Archaeological Research, Department of Archaeology and Anthropology, University of Cambridge, Downing Street, Cambridge, CB2 3DZ, UK

Email: jcf35@cam.ac.uk Telephone: +44 (0)1223 338256

\begin{abstract}
Demographic change has recently re-emerged as a key explanation for socio-cultural changes documented in the prehistoric archaeological record. While the majority of studies of Pleistocene demography have been conducted by geneticists, the archaeological records of the Palaeolithic should not be ignored as a source of data on past population trends. This paper forms both a comprehensive synthesis and the first critical review of current archaeological research into Palaeolithic demography. Within prevailing archaeological frameworks of dual inheritance theory and human behavioural ecology, I review the ways in which demographic change has been used as an explanatory concept within Palaeolithic archaeology. I identify and discuss three main research areas which have benefitted from a demographic approach to socio-cultural change; 1) technological stasis in the Lower Palaeolithic; 2) the Neanderthal-Homo sapiens transition in Europe, and; 3) the emergence of behavioural modernity. I then address the ways in which palaeodemographic methods have been applied to Palaeolithic data-sets, considering both general methodological concerns and the challenges specific to this time period. Finally, I discuss the ability of ethnographic analogy to aid research into Palaeolithic demography.
\end{abstract}

Key words: Demography, Palaeolithic, hunter-gatherers, behavioural ecology, cultural evolution

\section{Introduction}

"Un des problèmes les plus irritants de la préhistoire paléolithique est celui qui est lié aux factuers démographiques" (Bordes et al. 1972:26)

Demographic change has recently re-emerged as a key explanation for socio-cultural changes documented in the prehistoric archaeological record. Within wider research agendas of cultural evolution and cultural transmission theory (Boyd and Richerson 2005; Kuhn 2012; Shennan 2009a and papers therein), demographic change assumes a pivotal causal role in the understanding of variation in a wide range of archaeological material culture (e.g. Eerkens and Lipo 2005, 2007). As part of this evolutionary framework of cultural 'descent with modification,' population dynamics are viewed as the "single most important factor in understanding cultural change" (Shennan 2000:821) and regional demography and culture history are intimately and intrinsically linked. Aided by the increased precision of absolute dating methods, numerous recent studies document population patterns in the Holocene prehistoric archaeological record, exploring the relationships between demography, material culture, and environment (e.g. Armit et al. 2013; Attenbrow 2006; Bocquet-Appel et al. 2009; Crombé and Robinson 2014; Edinborough 2009; Hinz et al. 2012; Kelly et al. 2013; Kuijt 2009; Shennan 2001, 2009b, 2013; Shennan and Bentley 2008; Shennan and Edinborough 2007; Tallavaara and Seppä 2011; Tallavaara et al. 2013; Wicks and Mithen 2014; Williams et al. 2010).

While the primacy played by demography within this evolutionary framework is chronologically universal, the twin complications of the coarse resolution of absolute dating methods and the increase of data palimpsests has 
resulted in a situation in which the study of Pleistocene demography is largely the domain of researchers in fields other than archaeology. In particular, the work of population geneticists has highlighted the dynamic Pleistocene population history of both our own species and earlier hominins, transforming our understanding of the demography of Pleistocene foragers from a global history of slow growth rates and low population numbers (Hassan 1975 :41-42, 1981), to one of regional variation which saw population bottlenecks (Ambrose 1998; Excoffier 2002; Excoffier and Schneider 1999; Garrigan et al. 2007; Stajich and Hahn 2005), migrations and expansions (Achilli et al. 2005; Beaumont 1999; Jorde et al. 1997; Pereira et al. 2005; Ray et al. 2003), distinct geographical groupings (Fabre et al. 2009; Lalueza-Fox et al. 2011) as well as interbreeding between hominin species (Green et al. 2010; Neves and Serva 2012; Prüfer et al. 2014; Sankararaman et al. 2014; Wall et al. 2013).

Palaeolithic archaeologists are increasingly recognising the dynamic nature of Pleistocene demography, drawing on the results of both these genetic studies and mathematical models of the relationship between population and socio-cultural change (Shennan 2001; Powell et al. 2009). It is now widely acknowledged that processes of ebb and flow and local extinctions and colonisations characterised Pleistocene populations, representing responses to changing environmental and climatic conditions (Dennell et al. 2011; Gamble et al. 2004; Hublin and Roebroeks 2009). Utilising the independent estimates of population produced by other disciplines, demography is increasingly evoked as an explanatory variable for patterns seen in the Palaeolithic archaeological record. However, with some notable exceptions (e.g. Ashton and Hosfield 2010; Ashton and Lewis 2001; BocquetAppel and Demars 2000a, 2000b; Bocquet-Appel et al. 2005; Conard et al. 2012; French 2013; Grove 2010; Hosfield 1999, 2005; Mellars and French 2011, 2013; Morin 2008; Straus 2011; Straus et al. 2000), Palaeolithic archaeologists have been reluctant to use their own archaeological data to document and assess demographic change.

Archaeologists and anthropologists have long been sceptical of the ability of archaeological data to contribute to the study of Palaeolithic ${ }^{1}$ demography, suggesting that none of the palaoedemographic methods used in later periods are applicable to Palaeolithic data-sets (Yellen 1977:100), and reducing any results to "reasonable guesses" (Howells 1960:175). More recent critiques have considered the study of Palaeolithic demography from archaeological data an "inexact science" or "black art” (Kuhn 2012: 82) with specific studies (e.g. Mellars and French 2011) lauded as "courageous" but the methods used dismissed as "rarely reliable" (Dogandžić and McPherron 2013; cf. Mellars and French 2013). The applicability of palaeodemographic methods developed from the study of ethnographic and historical populations to pre-modern (Homo sapiens) hominins has also been called into question (Hassan 1981:84), posing problems for the study of demography from the Early and Middle Pleistocene archaeological records.

Despite these reservations, the archaeological record remains the best source of data on the hominin extinctions, replacements, expansions, and migrations that occurred during the $\sim 2.6$ million year span of the Palaeolithic; demographic processes which would have impacted considerably on long-term trajectories of socio-cultural and

\footnotetext{
1 In this paper I use the term 'Palaeolithic' to refer more broadly to the Pleistocene, recognising that there are continental variants used to describe the archaeological record of this period.
} 
artefactual change. Methods for estimating population size and densities from the Palaeolithic archaeological record are still in their infancy. Nonetheless, the archaeological record has the unparalleled potential to provide both a unique long-term perspective on Pleistocene demography, and direct empirical evidence from which to assess any results generated from the largely theoretical, or ethnographically-derived, models of the relationship between population size and culture which are currently dominating the research agenda (see Collard et al. 2013a).

This paper forms both a timely comprehensive synthesis and the first critical review of current archaeological research into Palaeolithic demography. This review comprises four main sections. I start by considering recent approaches to the study of demography within archaeology as a discipline, before reviewing the literature and analysing the implications of these approaches to our understanding of key features of the Palaeolithic archaeological record. I then move on from viewing demography as a purely explanatory concept, to assess critically the methods that archaeologists use to generate demographic patterns, focusing on the particular challenges of applying these to Palaeolithic data-sets. Finally, I examine the ethnographic record, discussing how, and to what extent, data on the demography of ethnographic hunter-gatherer groups can contribute to the study of Palaeolithic hunter-gatherer populations. While I adopt an explicitly critical stance to the potential pitfalls of studying Palaeolithic demography, the aim is not to imply that all demographic analyses founded on archaeological data are inherently and inescapably unreliable. Rather, the intention is to acknowledge the difficulties involved in studying prehistoric demography, identifying the theoretical and methodological challenges that are priorities for future research.

\section{Archaeological approaches to demography}

The study of demography has a long and varied history in archaeology (for summaries see Hassan 1978, 1981; Schacht 1981; Welinder 1979). Prior to the 1980s most studies adopted a Malthusian (1872) or Boserupian (1965) approach, in which population was seen respectively as either a dependent or independent variable in the relationship between food production, intensification, and population growth (e.g. Binford 1968; Childe 1936, 1950; Cohen 1975a, 1975b; Cowgill 1975a; Dumond 1965; Flannery 1969). As part of a wider research emphasis on adaptive explanations and the ecological basis of cultural change, processual archaeologists of the 1960s and 1970s embraced the Boserupian model of population as an independent variable in the process of socio- cultural change (Chamberlain 2006:4). Archaeological studies adhering to the Boserupian model focused on population as a 'prime-mover' (i.e. the primary causative factor), specifically population pressure caused by an upset in the equilibrium between population size and available food resources (see Bronson 1975; Cowgill 1975a, 1975b; Hassan 1974, 1975). Within this framework, population changes were viewed from the perspective of alterations in human adaptive systems.

Following the advent of Darwinian or Evolutionary archaeology in the 1980s (Dunnell 1978, 1980; see Shennan 2008 for a review), archaeologists have increasingly drawn on human behavioural ecology (HBE) and dual inheritance theory (DIT) to study demography. While both of these adhere to an evolutionary framework, they form two distinct, albeit largely complementary, research traditions, with HBE emphasising the role of natural selection in the evolution of human behaviour, and DIT emphasising the role of changing cultural traditions (Shennan 2008:78-79). Full reviews of these approaches are beyond the scope of this paper (see Bird and 
O'Connell 2006 for a review of HBE in archaeology and Shennan 2011, 2012 for DIT), and the focus here will be on the implications of their use to explore and explain past demographic change in the archaeological record.

\section{Human Behavioural Ecology and Life history theory}

One of the key developments in palaeodemographic theory in the past thirty years has been the increased consideration of the role of individuals in large-scale population processes. Drawing on ideas from HBE, specifically life history theory, several scholars have advocated studying the long-term population trends seen in the archaeological record from the perspective of the decisions of individuals designed to maximise their reproductive success (e.g. Boone 2002; Hammel and Howell 1987; Hill 1993; Read and LeBlanc 2003; Shennan 2002, 2009). Reproductive success does not necessarily correlate with the maintenance of a high birth rate, but instead the adjustment of fertility within optimal fitness-maximising strategies. This involves an adaptive tradeoff in resource and energy allocation between off-spring quality and quantity, reflected in variations in birth spacing, age at first birth, parenting strategies and mate selection and, when considering a range of hominins, additional biological factors such as maturation rate and brain and body size. (Borgerhoff Mulder and Schacht 2012:4-6; Winterhalder and Smith 2000). Environmental adaptation plays a key role in HBE, and strategies to maximise reproductive success are flexible and responsive to changes in a group's immediate environment (Shennan 2008:82). Due to this emphasis on environmental adaptations, the use of HBE, both generally and with regard to demography, has focused on forager populations (see Winterhalder and Smith 2000).

This emphasis on the actions of individuals has clear ramifications for how archaeologists think about past populations. When we view the agent of reproductive decisions as the individual rather than the abstract population (as seen in earlier processual studies; e.g. Cohen 1975a, 1975b, 1977; Harner 1970; Smith 1972), we reverse the interpretation of the resultant demographic pattern in the archaeological record: large-scale population trends become the result of multiple individual decisions triggered by personal experience and shortterm self-interest, not goals of biological self-regulation designed to maintain long-term equilibrium with the environment (Read and LeBlanc 2003:62; Shennan 2002:110, 2009b:340). However, the poor resolution of the archaeological record conflates multiple human generations into one chronological event, and only permits the study of long-term trends. As such, the demographic picture generated is likely to be false and unrealistically stable (Read and LeBlanc 2003:60; Shennan 2002:118-123). This also affects the geographical scale of study of past populations. A focus on global or continental population patterns is potentially misleading within a lifehistory framework as it refers to aggregates of populations rather than a population sensu stricto, at least as far as concerns reproductive possibilities (Hammel and Howell 1987:142). While a large geographical focus may help compensate for low chronological resolution, a regional perspective is preferred. Thus, while the resolution of the archaeological record may trick archaeologists into envisioning population changes as long-term, global events, such processes occur at the local level on a short-to-medium time-scale. The introduction of life history theory into the archaeological study of demography provides a useful framework to relate the low resolution archaeological record to the behaviour behind its formation.

\section{Dual inheritance theory}

Concomitant with the behavioural ecological approach is the increased use of a framework which explicitly links demography with the interpretation of material culture. Drawing on earlier studies (Boyd and Richerson 
1985; Cavalli-Sforza and Feldman 1981) archaeologists have investigated the material culture which forms the archaeological record in evolutionary terms (e.g. Collard and Shennan 2000; Eerkens and Lipo 2007; O'Brien and Shennan 2010; Powell et al. 2010; Richerson et al. 2009; Rosenberg 1994; Shennan 1996, 2000, 2002 , 2008, 2009a, 2011; Steele and Shennan 2009). Specifically, cultural changes, including those seen in material culture, are viewed within a framework of dual inheritance theory (Boyd and Richerson 1985) which maintains that humans (unlike other animals) have a second, cultural, inheritance system, in addition to the biological, genetic, inheritance system. This system of cultural inheritance is subject to evolutionary processes, and can be understood in ways analogous to that of genetic inheritance.

The system of cultural inheritance is that of social learning and changes are typically envisioned as innovations (Shennan 1996:175, 2002:38, 51). Unlike the biological inheritance system is which genetic information is transmitted only from parent to offspring, cultural transmission can take many forms, cross-cutting generations (i.e. transmission between peers) and often involving multiple individuals (i.e. one-to-many transmission) (Cavalli-Sforza and Feldman 1981:53; Powell et al. 2010:140; Shennan 2002:50). There are two main processes which cause variation in cultural traits through social learning; 1) guided variation, in which individuals modify their socially-learnt cultural adaptations through trial and error, and; 2) biased transmission, in which individuals adopt a cultural trait preferentially (Boyd and Richerson 1985; Powell et al. 2010:141; Shennan 1996:176). In addition, random, non-selective processes of cultural drift (broadly analogous to genetic drift) can occur, with chance variation impacting the frequency with which cultural practices are copied, irrespective of their inherent properties (Shennan 1996:176). Within this evolutionary framework, changes in the frequencies of different cultural traits in the archaeological record are a result of these various processes of social learning and random variation (Powell et al. 2010:141).

This model of cultural evolution has significant implications for the way in which archaeologists theorise the relationship between cultural change and past populations. Within the DIT framework, demography has a considerable impact on cultural evolution and material culture change through the effect of demographic change on both social learning practices and the frequency of random selection processes (Richerson et al. 2009:211). Mathematical modelling has demonstrated the prominent influence of population size on rates of innovation and maintenance of cultural traits ('cumulative culture') as well as the impact of social connectivity and transmission networks between populations and levels of population stability (e.g. Henrich 2004; Ghirlanda and Enquist 2007; Ghirlanda et al. 2010; Neiman 1995; Riede and Bentley 2008; Shennan 2001, 2006). Similar to the system of genetic inheritance, it is the effective population size (in genetic terms, the breeding population; in cultural terms, the number of 'cultural parents' or those who pass on culture to subsequent generations) rather than the absolute (census) population size which affects the transmission of cultural traits (Shenann 2001:8).

Shennan's (2001) model suggests both that innovations are more likely to occur in larger populations, and that any innovations are more likely to be maintained than in smaller populations, resulting in increased cumulative cultural complexity. Cultural drift (random selection) resulting in the loss of cultural traits and traditions is shown by Neiman (1995) to be negatively correlated with population size. The relationship between population size and cultural change has been famously cited by Henrich (2004), who attributes the loss of cultural traits in Holocene Tasmanian populations to a rapid reduction in population size (Henrich $2006 \mathrm{cf}$. Fitzhugh and Trusler 2009; Read 2006, 2012). Furthermore, decreases in population size may differentially affect the evolution and 
maintenance of cultural traits. Simpler technologies, for which the skills required for production and usage are easier to acquire, are more likely to persist than those which require one-on-one learning from a particularly skilled individual (Derex et al. 2013; Henrich 2004:204; Kempe and Mesoudi 2014; Kline and Boyd 2010 cf. Collard et al. 2005; 2013a, 2013b; Read 2012; see also Vegari and Foley 2014), although assessing the skill required to manufacture artefacts found in the archaeological record (and thus their relative complexity) is difficult (Bamforth and Finlay 2008).

Drawing on these studies, Riede (2009:312) has suggested inverting the link between cultural evolution and demography, using changes in material culture as archaeological proxies for past demographic change. However, it is unlikely that human population histories and cultural histories are identical, except in rare circumstances where vertical (parent-to-offspring) transmission of cultural traits is extremely strong (Shennan 2002:64). Nonetheless, the link espoused by DIT between archaeologically-visible material culture and the archaeologically-invisible processes of demographic change provides a firm theoretical framework for the study of prehistoric population patterns using archaeological data.

\section{Demography as an explanatory concept in the Palaeolithic}

Within the broad frameworks of HBE and DIT, Palaeolithic archaeologists are increasingly evoking demographic change as an explanation for key patterns and events documented in the archaeological record. I identify three main research areas where the application of a demographic approach has changed how archaeologists think about socio-cultural change in the Palaeolithic; 1) technological stasis in the Lower Palaeolithic; 2) the Neanderthal-Homo sapiens transition in Europe, and; 3) the emergence of behavioural modernity. In all three cases, demography contrasts with the dominant (but not mutually-exclusive) paradigm in which explanations for these phenomena are based on the perceived cognitive capacities of the hominins in question.

\section{1) Technological stasis in the Lower Palaeolithic}

One of the most intriguing features of the Lower Palaeolithic archaeological record is the conservative nature of Acheulean technological industries. Found across Africa and large parts of Eurasia from around 1.6 million to 100,000 years ago [kya] BP, the Acheulean is a hand-axe dominated industry characterised as homogenous and technologically static across its wide chronological and geographical range (Issac 1972; Leakey 1975). The slow pace of technological change and limited diversity seen in Acheulean industries is frequently attributed to cognitive and linguistic constraints (resulting in an ability to innovate) amongst the hominins (Homo erectus) who manufactured them (e.g. Binford 1989; Isaac 1972; Mithen 1996). Although geographical and chronological differences are apparent, these are seen to represent 'variations on a theme' rather than fundamental alterations in the technological and typological underpinnings of the industry (Lycett and Gowlett 2008; Pettitt and White 2012:171). Nonetheless, it is becoming clear that the Acheulean is less uniform than commonly claimed, particularly at the regional and assemblage/site based level (McNabb et al. 2004; Nowell and White 2010: 70-72).

According to Nowell and White (2010) one of the most puzzling features of the Lower Palaeolithic archaeological record is the contrast between the relative stasis in technology and the concurrent evolution of 
Middle Pleistocene hominin life histories. Drawing on ideas from HBE and DIT discussed above, Nowell and White (2010) have argued that the conservative nature of Acheulean industries has a demographic basis. They suggest the Lower Palaeolithic hominin populations were just too small for enduring change and technological advances to take place. The combination of low population numbers and wide dispersal and limited interconnectivity of Lower Palaeolithic groups meant that any innovations were unable to spread, resulting in a lack of cumulative cultural development, and a loss of skills associated with the innovation. In addition, they argue that the short duration of childhood and adolescence amongst Middle Pleistocene Homo erectus, would have limited the time individuals had to learn new skills, resulting in a situation where innovation was discouraged and in which the technological basis of Acheulean industries was imprinted early in the cultural learning process (Nowell and White 2010:76).

Hopkinson et al. (2013) take this idea further, emphasising the importance of Lower Palaeolithic metapopulations (the regional 'population of populations') to Acheulean technologies. They argue that in models linking demography and cultural innovation, it is the relationship between the local population and the regional population, rather than gross population size, which is crucial to the spread and persistence of cultural innovations and change (Hopkinson et al. 2013:65; see also Powell et al. 2009). In particular, the longevity of the local populations which comprise the metapopulation, and the social networks which bind them are key; factors which in turn are affected by local population sizes, territorial range and rate of migration and population aggregation and dispersal (Hopkinson 2011). Within this metapopulation model, Hopkinson et al. (2013) attribute widespread technological stasis in the Acheulean not only to small population sizes, but also limited territorial ranges and between-group migration, all of which contributed to short-lived local populations and the decreased likelihood of innovative behaviours being both disseminated and persisting.

Demographic explanations for technological stasis in the Acheulean are particularly persuasive as they explain one of the key contradictory features of the Lower Palaeolithic record: relative stasis and stability at larger chronological and geographical scales, with increased variation at the local level. Small population numbers, widely dispersed social groups, and frequent local group extinctions have all also been proposed to explain the perceived inertia of Middle Palaeolithic Neanderthal lithic industries, compared to those of the later Upper Palaeolithic (Bocquet-Appel and Tuffreau 2009: 296-297; Eerkens et al. 2013:1133; Premo 2012 ; Premo and Kuhn 2010; Hosfield 2005). In particular, Premo and Kuhn (2010) have stressed the importance of local population stability on culture change and diversity in both the Lower and Middle Palaeolithic. Using spatially explicit agent-based modelling, they show that increased rates of local group extinction can depress cumulative cultural change and diversity even when the metapopulation size remains stable, although the severity of this varies according to the level of intergroup cultural transmission and the extent of social networks (Premo 2012).

\section{2) Neanderthal-Homo sapiens transition in Europe}

The extinction of the Neanderthals and the subsequent colonisation of Europe by Homo sapiens (anatomically modern humans $[\mathrm{AMH}]$ ) populations remains one of the dominant research agendas in palaeoanthropology. While recent studies have demonstrated that some Neanderthal genetic material is still present in modern populations via inter-breeding between Neanderthals and early Homo sapiens (Green et al. 2010; Neves and Sera 2012), it is not the case that Neanderthals evolved into Homo sapiens, and their disappearance from the 
archaeological record 40 kya BP (Higham et al. 2014) reflects their extinction across their Eurasian geographical range. The Neanderthal-Homo sapiens transition is thus one of the most important demographic transitions documented in the archaeological record.

Despite this, research into this transition has traditionally focused on the cognitive differences between the two species which allowed AMHs to prosper while Neanderthals died out (Stringer and Gamble 1993; Wynne and Coolidge 2004; see Villa and Roebroeks 2014 for a review). Nonetheless, as early as 25 years ago, Zubrow (1989) using stable population models, demonstrated mathematically that small demographic differences between the two species could transform into large discrepancies in mortality and life expectancy, with an increment in Neanderthal mortality of 1-2\% leading to extinction within as little as 30 generations ( 1000 years) (although this model does not take into account recent genetic evidence for inbreeding between the two species). More recently, Sørensen (2011) constructed a model to assess Neanderthal demography relative to changing climatic conditions and resource availability, while keeping birth and death rates constant. Similar to the Zubrow model, small demographic differences, in this case a $1 \%$ reduction in death during childbirth and in death by hunting incidences between AMHs and Neanderthals, were crucial, permitting population growth amongst AMHs despite adverse climatic conditions 45 kya BP. These models both draw upon and reinforce osteological and biological evidence of life history advantages of early AMHs over Neanderthals (Caspari and Lee 2004, 2006; Guatelli-Steinberg 2009; Ramirez-Rossi and de Castro 2004; Smith et al. 2010; Trinkaus 1995 cf. Trinkaus 2012) as well as larger local group sizes amongst AMHs (Aiello and Dunbar 1993; cf. Steele 1996).

It is therefore surprising how few archaeological studies of the Neanderthal-Homo sapiens transition have explicitly evoked a causative role of demographic factors (e.g. Pettitt 2000; Wobst 1976). One particularly promising area of research addresses the adaptive advantages of AMHs over Neanderthals within the framework of HBE, using nutritional ecology to consider how differences in diet translate into demographic differences. 'Nutritional ecology' refers to the study of the relationship between essential nutrient intake (including both macronutrients (calories) and micronutrients (non-caloric vitamins and minerals)) and its effect on human health (Hockett and Haws 2003). Diversity of diet is linked to lower infant mortality rates and longer life expectancy. Stable isotope data (see Richards and Trinkaus 2009 for a review) and zooarchaeological assemblages suggest that Neanderthals had a very restricted diet, obtaining most of their dietary protein from large herbivores (e.g. Stiner et al. 2000). In contrast, AMHs consumed a diverse range of resources (Drucker and Bocherons 2004). Hockett and Haws $(2003,2005)$ have linked these findings into a model of Neanderthal extinction and AMH population replacement, suggesting that dietary broadening would have lowered maternal and fetal-to-infant mortality, as well as raising average life-expectancy amongst early European Homo sapiens populations, resulting in population increases.

While the study of nutritional ecology provides an archaeologically-visible 'way in' to the study of demography, recent research has revealed that plant foods played a much greater role in Neanderthal diets than previously supposed (Buck and Stringer 2013; Hardy 2010; Henry et al. 2014; Revedin et al. 2010) calling into question those studies which attribute the demise of the Neanderthals to high mortality brought about by limited nutritional diversity. A diet based entirely on terrestrial herbivores is also incompatible with estimates of Neanderthal calorific requirements and daily energy expenditure (Aiello and Wheeler 2003; Churchill 2006; Froehle and Schoeninger 2008; Pearson et al. 2006; Sorensen and Leonard 2001). Using an estimate of 5500 
calories required per day to sustain a pregnant Neanderthal woman, Hockett (2012) has shown that a diet from which these calories were derived exclusively from terrestrial herbivores would have killed a pregnant Neanderthal through protein poisoning, toxic levels of vitamin A, and the severe under-consumption of carbohydrates and vitamin C. While it is unclear from this example which part of the equation used to generate the calorific requirement estimate is wrong, Hockett's study serves to reinforce the bias in the archaeological record of dietary behaviour and incomplete understanding of various hominin diets. While the impact of nutrition on the fertility and mortality of Pleistocene populations is grounded in firm ecological theory, assessing these archaeologically is undeniably difficult.

Firmer estimates are available for Neanderthal population sizes and densities. While it is often assumed that Neanderthal group sizes and populations were smaller than early Homo sapiens, it is only recently that empirical evidence for this has been sought and linked explicitly into debates about the Neanderthal-Homo sapiens transition. Genetic evidence of Neanderthal effective (breeding) population sizes shows no clear consensus. Based on evidence from five Neanderthal mitochondrial (mtDNA) genomes, Briggs et al. (2009) postulated a mean Neanderthal effective population of between 268-3 510 individuals (95\% higher posterior density interval) and report low mtDNA diversity across the specimens, potentially reflecting a low effective population size over much of their history. Other estimates based on mtDNA range from 5 000-9 000 individuals (LaluezaFox et al. 2005) and, combined with a modelling approach, an effective population that ranges from 3000-25 000 (Fabre et al. 2009), with studies based on nuclear DNA suggesting sizes of between 3 000-12 000 (Green et al. 2006). However, generating absolute (census) population estimates from effective population size is difficult (Hawks 2008). Using a formula from conservation biology, Bocquet-Appel and Degioanni (2013) propose an estimated census population size of 5 000-70 000 Neanderthal individuals.

The Neanderthal-Homo sapiens transition is one of the few topics where researchers have also embraced the archaeological record as a source of demographic data. Drawing on a wide range of archaeological data, including faunal remains, site numbers, radiocarbon dates and quantities of lithic tools, several studies have attempted to provide relative estimates of the differences in both absolute population size and density and group size between Neanderthals and early AMHs (Bocquet-Appel and Demars 2000a (cf. Pettitt and Pike 2001); Burke 2006; Conard et al. 2012; Grayson and Delpech 2003; Hayden 2012; Mellars and French 2011, 2013; Morin 2004, 2008). In nearly all instances (cf. Morin 2004, 2008), the Neanderthal-Homo sapiens transition is associated with an increase in population density of potentially up to 10 times that seen amongst Neanderthals (Conard et al. 2012; Mellars and French 2011, 2013 cf. Dogandžić and McPherron 2013). Using the order-ofmagnitude difference documented by Mellars and French (2011) for Southwestern France, Bocquet-Appel and Degioanni (2013) proposed census population sizes for the region of 80-1,300 Neanderthal individuals, contrasting with an estimate of 795-12 980 AMHs during the Aurignacian (Bocquet-Appel et al. 2005).

The results of these studies suggest that sheer strength in numbers can help explain the demise of Neanderthals and the eventual success of AMHs, without recourse to any perceived cognitive advantages of one species over another. It may simply be the case that Neanderthal populations declined below their Minimum Viable Population (MVP) threshold (the threshold population size below which a species will go extinct; Gilpin and Soulé 1986; Reed et al. 2003; Shaffer 1981), either coincidental to the arrival of AMHs into Europe, and/or abetted by the resultant increased competition for resources. While the fact that both Neanderthals and early 
AMHs in Europe lived in broadly similar environments (and likely overlapped for up to 5000 years; Higham et al. 2014) means that some adaptive advantage of AMHs still needs to be evoked (how exactly did they manage to support greater population densities in the same environments?), the increasing number of demographic studies of this transition can help to identify these potential adaptive differences, while recognising that it is small but cumulative effects of changes in demographic variables (fertility, mortality) which translate into longterm archaeologically-visible population trends.

\section{3) Emergence of Behavioural Modernity}

Perhaps the most well-known example of a demographic approach to the Palaeolithic archaeological record is that which applies notions of innovation and cumulative culture to the appearance of evidence for 'behavioural modernity'. While the concept of 'behavioural modernity' remains contentious and ambiguous (d'Errico 2003; d'Errico and Banks 2013; Henshilwood and Marean 2003 (and comments therein); Nowell 2010) it broadly refers to a suite of behaviours which are typically (but not necessarily exclusively; Zilhão 2007) associated with Late Pleistocene AMHs, and which are taken to indicate the presence of modern-level linguistic and cognitive abilities. These are identified in the archaeological record through the presence of such objects and behaviours as deliberate burials, complex lithic and hafting technologies, personal ornamentation, pigment use and 'symbolic' art and artefacts (e.g. Henshilwood and Marean 2003; McBrearty and Brooks 2000; Mellars et al. 2007). The appearance of these behaviours in the archaeological record was originally envisioned to have occurred 40-35 kya BP with the advent of the European Upper Palaeolithic, coincident with the arrival of the earliest AMHs in Europe (Mellars 1973, 1990; Mellars and Stringer 1989; White 1982). Evidence of these behaviours, which contrasted greatly with those seen in the earlier (Neanderthal) Middle Palaeolithic record, were viewed as a dramatic and sudden change, resulting in the term 'Human Revolution' being applied to the initial appearance of behavioural modernity in the archaeological record. The concurrent appearance of both anatomical and behavioural modernity led to the equation of biology and culture, with the absence of similar features in the Neanderthal archaeological record reflecting their lack of the necessary cognitive abilities (e.g. Mithen 1996).

Over the past 25 years, increased knowledge of the archaeological records of other regions of the world, particularly Africa, has questioned the uniqueness of the Upper Palaeolithic 'revolution'. The African Middle Stone Age, chronologically contemporary to the European Middle Palaeolithic, and associated with AMHs, shows many of the behaviourally modern elements previously considered unique to the European Upper Palaeolithic. The evidence from Africa suggests that the appearance of these behaviours occurred gradually in a piece-meal fashion from 300 kya BP (McBrearty 2007; McBrearty and Brooks 2000). Nonetheless, the earliest convincing evidence for modern behaviour dates to 164 kya BP, at the site of Pinnacle Point, South Africa (Marean et al. 2007) and the earliest evidence for symbolic behaviour dates to 75 kya BP at Blombos Cave, South Africa (d'Ericco et al. 2001; Henshilwood et al. 2004; Henshilwood 2007) with possible earlier dates of 90-100 kya BP in the Near East (d'Errico and Vanhearen 2007). As such, there is an apparent time lag between the appearance of modern human biology and modern human behaviour in the archaeological record. In addition, instances of 'modern behaviour' amongst Neanderthals are cited (e.g. Zilhão 2007; Zilhão et al. 2010), and research has demonstrated an increase in the number and diversity of putative 'modern' behavioural elements across the chronological span of Neanderthal occupation of Eurasia (Langley et al. 2008). The 
resultant situation is one in which behavioural modernity is not necessarily a species-specific phenomenon, and in which different markers of modern behaviour emerged at different times. The question still remains as to why evidence of behavioural modernity appears in the archaeological record when and where it does, especially in instances where the equation of modern anatomy and modern behaviour is a matter of debate, rather than a given (Nowell 2010).

Drawing on DIT frameworks, Shennan (2001) proposed a demographic basis for the emergence of behavioural modernity. In Shennan's model, the emergence of behavioural modernity is explicitly linked to population size, with demographic growth and larger population networks providing the impetus both for the increased occurrence and maintenance of behavioural innovation, resulting in greater cumulative cultural complexity. This model was later expanded by Powell and colleagues (2009) who also argued for a demographic basis for the emergence of behavioural modernity, stressing the importance not only of population size and density but also the degree of interaction and migration of the constituent sub-populations on the accumulation of cultural traits (cf. Vaesen 2013). Based on genetic estimates of regional population size, Powell et al. (2009) provided estimates for the critical effective population necessary for the accumulation of modern behavioural traits, noting that population density at the start of the European Upper Palaeolithic was similar to that found in subSaharan Africa 45000 years earlier, where behavioural modernity first emerged. This model has the advantage of explaining several key features of the archaeological record of behavioural modernity, including the time-lag between its initial emergence and its wide-scale presence, as well as the geographical and chronological variation in the first appearance of such behaviour (see also Richerson et al. 2009). Furthermore, as it does not rely on inferred cognitive capacities as the explanatory variable, changes in population size and connectivity can be used to assess incidences of modern behaviour associated with earlier Neanderthal populations.

Other researchers have considered whether demographic change explains specific patterns of the emergence of behavioural modernity, focusing on both the Australasian (Brumm and Moore 2005; Langley et al. 2011; O’Connell and Allen 2007) and South Asian (James and Petraglia 2005) archaeological records. Langley and colleagues (2011), for example, note a decrease in the evidence for complex 'modern' behaviours in the archaeological record of Sahul corresponding with reduced and fragmented populations during the Last Glacial Maximum. Hovers and Belfer-Cohen (2006) have also suggested a role of small populations and repeated population crashes in the sporadic occurrence of 'modern' behavioural traits in the Middle Palaeolithic Neanderthal record, positing a situation where behaviours and technologies were repeatedly invented as demographic instability never permitted the retention of cultural knowledge or the accumulation of the skills required for the manufacture and use of innovative technologies. While we should resist the temptation to replace one prime mover for the emergence of behavioural modernity with another (d'Errico and Banks 2013), it is clear that a demographic approach to this research question has considerable utility. While the reality is likely somewhere between the dichotomy of behavioural modernity emerging as a result of "get[ting] smart or just get[ting] together" (Culotta 2010), a demographic approach has the advantage of permitting both the accommodation of local historical trajectories into any model of behavioural change, and being more archaeologically testable than explanations based on proposed cognitive or mental capacities (e.g. Klein and Steele 2013). It is to this issue of the archaeological testability of demographic hypotheses that we now turn. 


\section{The application of palaeodemographic methods to the Palaeolithic archaeological record}

DIT and HBE have provided vital frameworks for the study of archaeological demography. Yet the application of these approaches, particularly DIT, to Palaeolithic data is not unproblematic. It is not enough simply to acknowledge the conceptual link between cultural change and population change; how, for example, do we measure and quantify rates of change and innovation in material culture? Studies of ethnographic huntergatherer groups focus on the diversity and complexity of their tool-kits (Collard et al. 2005, 2011, 2013a, 2013b; Henrich 2004; Read 2008). These measures have been applied to archaeological hunter-gatherer data-sets from the terminal Pleistocene and Holocene (Bettinger and Eerkens 1999; Edinborough 2009; Eerkens et al. 2013; Fitzhugh and Trusler 2009; Riede 2008), as well as cladistic analyses constructing phylogentic trees documenting the evolution of specific material culture traits (Buchanan and Collard 2007; O'Brien and Lyman 2003; O'Brien et al. 2001, 2014). Within DIT, documenting patterns in material culture relies on measures of dispersion and variation, rather than describing the average tendency of artefact assemblages (Eeerkens et al. 2013). Measuring such changes with the majority of Palaeolithic datasets is difficult, and, with few exceptions, studies linking changing material culture and population are often restricted to comparing broad artefact typologies (e.g. Bocquet-Appel and Tuffreau 2009). In particular, the Lower and Middle Palaeolithic records do not lend themselves to fine-grained quantitative analysis of cultural transmission (Smith et al. 2009:175), as they primarily represent aggregates of behaviour. It is especially challenging to infer the means of cultural transmission between individuals (Mesoudi and O'Brien 2009; Premo 2014) and researchers studying the same archaeological record have reached different conclusions about the type of cultural transmission which produced the assemblages in question (e.g. compare Nowell and White 2010 and Lycett and Gowlett 2008 for the Acheulean (Lower Palaeolithic)). These difficulties have led Richerson and Boyd (2008:302) to suggest that archaeologists should play to disciplinary strengths of the study of long-term change, rather than attempting to fit micro-evolutionary approaches directly to their data.

In addition, Collard et al. (2013a) have recently claimed that the empirical ethnographic evidence supporting the relationship between population size and cultural evolution for hunter-gatherers is ambiguous. Unlike among small-scale food producers (Collard et al. 2013c; Kline and Boyd 2010), other variables, including adaptation to changing environmental conditions and risk of resource failure, have a greater effect than demography on the structure and complexity of hunter-gatherer tool kits (Collard et al. 2005, 2011, 2013b; Read 2008, 2012). They warn that "more caution is needed" (Collard et al. 2013a) by Palaeolithic archaeologists citing population size as an explanation for patterns seen in the archaeological record. Overall, DIT and cultural evolutionary models in Palaeolithic contexts function at present primarily as broad explanatory frameworks, rather than robust methodologies for the study of the relationship between demography and material culture. Finding ways in which to reconcile these frameworks with our data is a clear priority for the study of Palaeolithic demography. Leaving aside these methodological difficulties, the majority of studies of Palaeolithic demography based on evolutionary frameworks have two fundamental shortcomings; 1) they rarely address the causes of population changes, and; 2) they rarely provide empirical evidence that the population change evoked as part of the explanation for patterns seen in the archaeological record actually occurred. The rest of this review will focus on this latter point. While the models derived from other fields provide a useful starting-point for the study of Palaeolithic demography, to assess their validity we need to acquire independent, archaeological, evidence for 
prehistoric demography (Shennan 2011:1078). While assessing demographic patterns from archaeological data is far from easy, as Hopkinson et al. (2013:70) rightly point out, it is a no more difficult task than providing evidence for the cognitive abilities which frequently form the main competing explanation.

\section{Demography and prehistoric demography}

It is useful at this point to reiterate the basis of demography. Three demographic variables (measured as rates) are the immediate causes of all population change past and present; 1) Fertility (the process by which a population bears children); 2) Mortality (the process by which the members of a population are reduced by death), and; 3) Migration (both immigration and emigration) (Hinde 2002:18). Demographic change is the result of variation in at least one of these variables, which cause further changes in the size, density, and growth rate of the population (Daugherty and Kammeyer 1995:11).

As fertility, mortality, and migration govern population change demographers need to know their rates and what causes them to alter (Weeks 1999:70). Unfortunately, data on these variables are unavailable from the archaeological record. Prehistoric demographic analysis (palaeodemography) is thus restricted to the study of the results of changes in these three parameters; namely, relative chronological and geographical changes in population density, distribution, and size, with little recourse to the specific demographic variations that caused these changes ${ }^{2}$ (Beaton 1991). As such, Palaeolithic demography primarily involves documenting population trends, rather than producing population estimates, concentrating on trends in census (i.e. total) population sizes, rather than the effective population sizes crucial to DIT (although relative estimates could be made assuming that the effective population is approximately $1 / 4$ of the census population; Shennan 2001:8). This enforced focus on the outcome of variation in demographic variables is also difficult to explicitly reconcile with the HBE framework and the role of individual decisions in demographic change.

The four most common methods used to study demography from archaeological data are listed in Table 1 and discussed below. While the emphasis is on the application of these to Palaeolithic data-sets, many of the debates surrounding the use of these methods are chronologically universal, and in the absence of up-to-date summaries (see Hassan 1978, 1979, 1981; Paine 1997; Schacht 1981; Welinder 1979), some general discussion of these approaches is included where appropriate. Similarly, I have chosen not to consider the use of osteological evidence in archaeological demography, as this has been the topic of several recent reviews (Bocquet-Appel 2008a, 2008b; Chamberlain 2006, 2009; Monge and Mann 2007).

\section{The nature of palaeodemographic evidence}

Regardless of the method used, two factors complicate all attempts to use archaeological data to study demography. Of these, the most fundamental is the reliance on proxy data; the archaeological material itself contains no direct demographic information (see Chapman 1999). As such, archaeologists require some form of theoretical 'leap' to move from the observed pattern in the archaeological record to an understanding of past demography, usually following a principle of uniformitarianism (Fritz 1972). The methods listed in Table 1

\footnotetext{
${ }^{2}$ Although some estimates of changes in fertility and mortality rates have been (questionably) inferred from osteological remains (e.g. Buikstra and Konigsberg 1985; Buikstra et al. 1986; Greene et al. 1986; Konigsberg and Frankenberg 2005; cf. Bocquet-Appel and Masset 1982; Corruccini et al. 1989; Petersen 1975), and such parameters can be modelled (Sørensen 2011; Surovell 2000).
} 
provide the means to convert the archaeological proxies into meaningful statements about demographic change. While the assumptions behind these approaches are plausible, the extent to which they are valid in the present (and hence applicable to the past) is largely unconfirmed (e.g. Levinson 1979). Part of the problem is that modern day demography is based on observation rather than experiment (Daugherty and Kammeyer 1995:79), providing little impetus to examine the inferred relationships between population and the proxies used by archaeologists. In addition, all of these approaches suffer from the problem of equifinality; multiple valid explanations can be evoked to explain the patterns seen in the data. For example, different rates of artefact accumulation between sites could reflect occupation by groups of different sizes, but could also reflect cultural changes in consumption or varying lengths of occupation (e.g. Heizer 1960: 93; Hiscock 1986; Ross 1985:8283). Differentiating between the possible explanations and demonstrating conclusively that the pattern in the proxy data reflects past demographic change remains one of the greatest challenges of palaeodemography. For hunter-gatherer populations, such as those present during the Palaeolithic, the most frequently cited alternative explanation for patterns generated through the use of the methods listed in Table 1 is a change in mobility strategy or land-use patterns (e.g. Attenbrow 2006).

The other fundamental difficulty is what is termed 'the contemporaneity problem' (Schacht 1984). This refers to the practice of considering remains dated to the same general period as contemporary, despite it being unlikely that they are strictly contemporary. This problem results from the use of data in accumulated form (Ammerman et al. 1976) which makes it hard to assess whether the material represent a discrete occupation episode or a palimpsest of past activity; whether the occupations were simultaneous or sequential. In demographic terms, this distorts estimates of past populations by combining centuries or millennia into a single time phase (Freter 1997), ignoring elements of change within the defined periods, and forcing a reliance on the equation of 'populations' with certain classes of material culture. This problem of (lack of) chronological precision is one of the primary obstacles within palaeodemography, and means that any demographic data generated is difficult to reconcile with both DIT and HBE frameworks (for attempts to overcome the contemporaneity problem see; Ammerman et al. 1976; Grove 2012; Hill 1970; Plog 1975; Schacht 1981).

While these difficulties are common to all palaeodemographic analyses, they are particularly pertinent when dealing with the Pleistocene archaeological record. The range of cultural material available as proxy data is more restricted and problems of data resolution and occupation palimpsests are more pronounced than for later prehistoric periods (Conard 2001). The wide margins of error associated with any chrono-metric date and the applicability of ${ }^{14} \mathrm{C}$ dating only after $\sim 40$ kya BP (Higham 2011), coupled with the long-standing importance of generalisation with Palaeolithic archaeology (Hopkinson and White 2005), forces an increased reliance on typologically-derived relative chronological sequences, making it even more difficult to ascertain contemporaneity of occupations. Nonetheless, these problems are reduced if we are primarily interested in the study of patterns of relative, long-term, population change and if a multi-proxy approach is adopted, comparing and contrasting the results generated from each.

Site counts and 'dates as data'

The number and distribution of archaeological sites is commonly used as a demographic proxy following the assumption that variations in these data reflect proportional fluctuations in the relative size and distribution of 
past populations. This approach is well-suited to application to Palaeolithic contexts. Archaeological 'sites' are defined by the presence of a chronological distinctive artefact type (cf. Smith and Sharp 1993), which are typically robust and survive well in the archaeological record. As such, while the ideal situation is to produce maps of site numbers and distributions based on radiometrically defined time-slices from archaeological deposits (Petraglia et al. 2009; Straus et al. 2000), in the absence of absolute dates, or if the data came from survey rather than excavation, sites can still be included and dated by reference to artefact typologies. The use of typology as a way of assigning sites to chronological periods both permits the extension of the approach to those stages of the Pleistocene which are difficult to date radiometrically, and limits taphonomic bias relative to timedepth through the use of virtually indestructible lithic artefacts as diagnostic markers (Bocquet-Appel et al. 2005:1664).

The use of site counts as a demographic proxy has been applied to Palaeolithic data sets at both the regional (David 1973, 1985; Demars 1996, 1998; French 2013; Mellars and French 2011; Schmidt et al. 2012; Smith 1966; Straus 2011; Straus et al. 2000) and continental level (Anderson and Faught 2000; Bocquet-Appel and Demars 2000b; Bocquet-Appel et al. 2005; Lahr and Foley 2003; Petraglia et al. 2009; van Andel et al. 2003), using the archaeological records of both AMHs and earlier hominin species. To accommodate for the uneven lengths of any periods under consideration, site counts are frequently standardised and expressed as a value of number of sites/1000 years. The European Upper Palaeolithic ( 40 -10 kya BP) has proven particularly amenable to this approach, with long histories of research in key areas (for example, the refugium zone of Southwestern Europe (France, Iberia)) enhancing the representativeness of site numbers and distribution as proxies of past populations (Mellars and French 2011; Schmidt et al. 2012; Straus et al. 2000). While the majority of studies are restricted to using site counts to assess relative chronological differences in demography, Bocquet-Appel and colleagues (Bocquet-Appel and Demars 2000b; Bocquet-Appel et al. 2005) have used these data to arrive at absolute estimates for metapopulation sizes across the European Upper Palaeolithic. Drawing on ethnographic data from hunter-gatherers, they calculated a demographic density (per $100 \mathrm{~km}^{2}$ ) for four periods of the Upper Palaeolithic (Aurignacian, Gravettian, Glacial Maximum and Late Glacial) by backprojecting a reference density for the Late Glacial with inter-period growth rates based on the numbers of archaeological sites. Absolute estimates were then obtained by multiplying the demographic density with the perceived territory size generated through modelling the geographical distribution of sites (Bocquet-Appel et al. 2005). While there are undoubtedly difficulties with the use of ethnographic data in Palaeolithic contexts, the combination of ethnographic and archaeological data used by Bocquet-Appel and colleagues has produced the most well-founded estimates of absolute population numbers for the Palaeolithic to date.

Nonetheless, there are several methodological difficulties with this approach. These include; 1) questions about whether the inclusion of non-habitation sites (e.g. burials, rock-art locations) is appropriate for assessing past population changes (Bird and Frankel 1991; e.g. compare the criteria adopted by Smith and Sharp 1993 and Straus et al. 2000); 2) the influence of under-or-over-weighting of sites of varying sizes if all sites, from isolated find-spots to large habitation sites, are treated as equal (Bocquet-Appel et al. 2005: 1658) and the potential for differential preservation of sites of varying sizes and functions (including differences between sheltered and open-air sites); 3) the impact of sampling and fieldwork bias on the known number and distribution of sites; 4) the differential visibility and recognisability of diagnostic artefact types, and the potential that distinctive or 
visually impressive types (e.g. Solutrean points of the European Upper Palaeolithic; Straus et al. 2000) may inflate site numbers for a given period; 5) that the use of typological markers restricts our study to population changes between chrono-typological periods, obscuring any likely changes within these periods, and ; 6) how to accommodate geographical areas and periods where chronologically diagnostic artefacts are lacking (e.g. Holdaway et al. 2005; Kuzmin and Keates 2005). By far the most pertinent difficulties as far as Palaeolithic data-sets are concerned are problems of chronological control and the aforementioned 'contemporaneity problem' (Schacht 1984), with sites that date from the same period of often multiple millennia plotted on maps and treated as if they represent an accurate 'snapshot' of past population distributions.

One popular method which reduces this problem of poor chronological control is the use of summed probability distributions of radiocarbon dates as a demographic proxy ('dates as data'; Rick 1987). This approach is based on the same assumption as the use of site counts, with relative changes in the frequency and distribution of ${ }^{14} \mathrm{C}$ dates argued to reflect variations in past population sizes and densities (Riede 2009). The validity of this assumption is enhanced in regions with long and intensive research histories and for which a large number of ${ }^{14} \mathrm{C}$ dates are available (Shennan and Edinborough 2007; Williams 2013), as potential biases caused by research focuses, intensity and budgets are well known, if frequently underestimated (Crombé and Robinson 2014; Williams 2012; van Andel et al. 2003). The exact nature of the relationship between radiocarbon dates and population is frequently assumed to be linear and uniform throughout time (cf. Peros et al 2010) although this remains untested.

While archaeologists have most extensively applied the 'dates as data' approach to Holocene prehistoric archaeological records (Armit et al. 2013; Barrientos and Perez 2005; Blockley 2005; Bocquet-Appel et al. 2009; Crombé and Robinson 2014; Hinz et al. 2012; Johnson and Brook 2011; Kelly et al. 2013; Martínez et al. 2013; Munoz et al. 2010; Neme and Gil 2009; Peros et al. 2010; Riede 2009; Shennan 2009b, 2013; Shennan and Edinborough 2007; Shennan et al. 2013; Tallavaara and Seppä 2011; Tallavaara et al. 2010; Wicks and Mithen 2014; Williams et al. 2010; Woodbridge et al. 2012), it has also been applied to Pleistocene datasets, most prominently those of the European Upper Palaeolithic (Anderson et al. 2011; Bamforth and Grund 2012; Blackwell and Buck 2003; Blockley and Gamble 2012; Blockley et al. 2000; Buchanan et al. 2008; Collins 2012; Fiedel and Kuzmin 2007; Gamble et al. 2004, 2005; Graf 2009; Kuzmin 2009; Kuzmin and Keates 2005; Meeks and Anderson 2012; Schmidt et al. 2012). Attempts have also been made to apply similar approaches to earlier records, most noticeably Bocquet-Appel and Demars' (2000a) study of Neanderthal demographic contraction and AMH expansion in Europe (but see Pettitt and Pike 2001). Despite the increasing use of complex Bayesian models to manage large databases of radiocarbon dates, the limits of radiocarbon dating (currently 50-40 kya BP; Higham 2011) restrict the use of the 'dates as data' approach to only the later stages of the Pleistocene. In any case, it is inadvisable to conduct meta-analyses of radiocarbon dates without the prior application of criteria to assess their reliability, particularly with Palaeolithic dates (e.g. Pettitt et al. 2003).

Two main issues hamper the use of site counts and radiocarbon dates as demographic proxies. The first of these is taphonomic. Surovell and colleagues (Surovell and Brantingham 2007; Surovell et al. 2009) have demonstrated that the positive curvilinear distributions regularly observed in these proxies in the archaeological record also occur in natural paleontological and geological contexts (see also Ballenger and Mabry 2011; Johnson and Brook 2011 cf. Riede 2009). The findings of their studies suggest that any trends should be treated 
with caution and could instead be interpreted in terms of increased taphonomic loss with time-depth, unless some form of 'correction curve' is applied (Surovell et al. 2009). To prevent any patterns simply reflecting a bias against older sites in the archaeological record, Surovell and colleagues advocate their comparison with the underlying geological formations of the study region, or using the distribution of more geologically-protected cave and rock-shelter sites as a check against the frequency distributions of open-air sites and any radiocarbon dates which come from them (e.g. Kelly et al. 2013).

The second main issue is the aforementioned problem of equifinality. Past human behaviours —whether dependent or independent of population fluctuations - could also impact on the number and distribution of archaeological sites and radiocarbon dates. As mentioned earlier, for hunter-gatherer groups, the most cited alternative explanation for variation in these proxies is a change in mobility strategy and land-use patterns, with an increased signature interpreted as representing periods of higher mobility (e.g. Attenbrow 2006; Niekus 2005/2006; Tallavaara et al. 2010:253). This could relate to differences in overall group mobility strategy which impact how often hunter-gatherer groups move home bases and the number of non-residential sites they generate (e.g. Binford's (1980) continuum of 'logistic' and 'residential' mobility), or seasonal/annual population aggregations and dispersals following the 'fission-fusion' pattern well-documented amongst ethnographic hunter-gatherers (Aureli et al. 2008; Layton and O'Hara 2010). Ways of looking at changing patterns of mobility include considering such additional factors as the size of archaeological sites, seasonality of occupation, quantity and diversity of associated artefactual remains, and extra locational data, such as elevation and spatial distribution (Bocquet-Appel et al. 2005:1658; Conkey 1987; French 2013; Perreault and Brantingham 2011; Wadley 1987).

Site size

The most common of these additional factors is that of site size, following the assumption that there is a positive correlation between the size of the site and the number of people who inhabited it (Ammerman et al. 1976; DeRoche 1983; Plog 1975; Schacht 1981:125; Welinder 1979:34 cf. Schreiber and Kintigh 1996). Studies of later prehistoric and historic periods incorporate both relative and absolute population and group size estimates based on the area and number of dwelling structures present (Brown 1987; Casselberry 1974; Casteel 1979; Cook and Heizer 1968; Curet 1998; Davies 2010; DeRoche 1983; Haviland 1969; Hill 1970; Kolb 1985; Kramer 1980,1982; Kuijit 2000; LeBlanc 1971; Longacre 1976; Milisauskas 1972; Milner 1986; Naroll 1962; Odell 1980; Phillips 1972; Porčić 2011, 2012; Postgate 1994; Read 1978; Storey 1997; Sumner 1979; Thompson 1971; Wiessner 1974). Due to the rarity of dwelling structures in the Palaeolithic archaeological record and the difficulty of distinguishing between habitation and non-habitation space at sites (Yellen 1977), the focus here will be on the use of overall site size as a demographic proxy.

Palaeolithic archaeologists have used the relationship between site area and number of individuals as a proxy measure for group size, investigating both inter- and intra-site chronological variations (Burke 2006; French 2013; Hayden 2012; Mellars 1973; Mellars and French 2011, 2013; White 1985). For example, Mellars and French (2011) noted that in Southwestern France final Neanderthal (Châtelperronian) sites were on average markedly smaller than those associated with early AMHs (Aurignacian) (means of $64.7 \mathrm{~m}^{2}$ and $243.8 \mathrm{~m}^{2}$ respectively). They interpreted this difference as evidence of smaller living groups of Neanderthals compared to 
early AMHs in the region. Several of the estimates used in their study came from the same site, strengthening the interpretation of group size influencing site area, as smaller areas of occupation were documented during the Châtelperronian despite room for expansion.

Several difficulties with this approach have led to the use of site size as a demographic proxy having limited application to Palaeolithic contexts. The primary difficulty is defining the limits of the site, which is usually determined by the extent of the spatial distribution of material culture. This can be hard to ascertain, especially when the site has not been excavated in its entirety, or when the estimate is based on survey data (Fletcher 1981:102; Newell 1973; Phillips 1972). This problem is compounded by the need to make the data comparable between sites, meaning that the often lower-quality data on site size from older excavations form the basis of the comparison, limiting the use of higher-quality spatial data from more recently excavated sites. Site size estimation is also hampered by the problem of occupation palimpsests. It is frequently unclear how many occupation episodes are represented by the archaeological remains at a site, and the extent to which successive visits caused the zones of occupation to shift laterally. In other words, large sites could be the result of the single occupation of a large group, or successive (re)occupations by smaller groups. In contrast, small sites could only feasibly have been occupied by small groups. Thus, while there is some ambiguity involved in correlating group size and site size as far as larger sites are concerned, the assumption that small sites reflect occupation by small groups is reasonably sound. This is especially so where the site area is either spatially constrained or remains small, despite the potential for occupation of a greater area. As such, estimates of site size for the Palaeolithic are much more secure for cave/rock-shelter sites than for open-air sites, where the lack of spatial constraints and the increased occurrence of horizontal displacement of artefacts (Lenoble et al. 2008: 108) make estimates much cruder (although the occupation and use of spaces in front of formal dwelling areas (including caves/rockshelters; White 1985) is common and can hamper size estimates (LeBlanc 1971; O’Connell 1987; Wiessner 1974)). The difficulty of accurately determining site areas has led to many estimates of Palaeolithic group sizes being based on osteological data, particular for pre-modern hominins (Aiello and Dunbar 1993; Burke 2006; Mithen 1996; Steele 1996). Recently, Grove (2010) has developed a method to estimate group size for both archaic hominins and Homo sapiens, using a spatial model of archaeological site distribution combined with an estimate of population density based on body mass. He notes a general trend of increased group size throughout time, which accelerates at the advent of the European Upper Palaeolithic ( 40 kya BP), combined with general increases in population size and density.

Issues of interpretation also complicate the link between population and site size. The specifics of the relationship between site size and number of individuals are ambiguous, although Hamilton et al. (2007a) have recently proposed an allometric relationship (i.e. the area required per person changes as site area increases) between the two variables for hunter-gatherers. Similarly, variations in the area of archaeological sites can also be interpreted in terms of mobility either referring to the total duration of occupation, the anticipated duration of occupation or the frequency of re-occupation (Kelly et al. 2005; Kent 1991, 1992; Kent and Vierich 1989; Yellen 1977). It is logical that the amount of refuse generated by a group would increase to some degree with an increased duration of residence (regardless of the absolute size of the group), and that, where no geographical barriers exist, the likelihood of the habitation area expanding is similarly increased, due to a desire to maintain a distance between different activity areas. Likewise, successive re-occupations of the same site are liable to 
expand the settlement limits, as groups shift the central zone of occupation laterally to avoid the debris from previous occupations. One way of examining this is to combine data on site size with data on the number of sites; we may be looking at chronological changes in mobility rather than group size or overall population density if there are more sites, but these are on average smaller. Conversely, a reduction in both site numbers and site sizes provides stronger evidence for a reduction in relative population density. However, the aforementioned problem of contemporaneity of occupation again comes into play, as a regional population utilising a series of sites sequentially would look very similar archaeologically to a population that was large enough to occupy all sites simultaneously (Grove 2010:403). While the broad intuitive trend that more people generally take up more residential space holds for hunter-gatherers (Hamilton et al. 2007a) several scholars have demonstrated the impact of other factors on site size, including kinship ties between group members (Binford 1991; Fletcher 1991; Whitelaw 1983, 1991), risk of predation (Gould and Yellen 1987) and subsistence base (Hamilton et al. 2007a), all of which may also have affected Palaeolithic hunter-gatherers.

\section{Accumulations research}

The use of quantities of material culture ('accumulations research'; Gallivan 2002; Kohler and Blinman 1987; Ramenofsky et al. 2009; Varien and Mills 1997; Varien and Ortman 2005; Varien and Potter 1997) as a demographic proxy relies on the assumption that there is a positive correlation between the amount of material discarded at a location and the number of people who inhabited it (Ammerman et al. 1976:31). Accumulations research employs models based on the use and disposal of a given class of occupation residue to calculate rates of accumulation (often expressed as the amount of material/area or volume unit, for a given length of time (e.g. Attenbrow 2006; Neme and Gil 2009)) to examine variation in relative population numbers. Attempts have also been made to use accumulations research to estimate absolute population numbers, based either on sophisticated 'discard equations' (Schiffer 1975, 1976:59, 1987; see for examples Gallivan 2002; Kohler and Blinman 1987; Pauketat 1989; Varien and Potter 1997), or calculation of the calorific value of the faunal remains at a site and the number of individuals this could feasibly sustain (Ascher 1959; Cook 1946; Glassow 1967; Wheat 1972). The use of discard equations to obtain absolute population estimates relies on accurate data on such variables as the use-life of artefacts and the time span over which the material accumulated. As this information is only available in rare archaeological instances (e.g. Varien and Potter 1997), and never for the Palaeolithic, the rest of the discussion is limited to the use of accumulations research for the comparative analysis of relative population numbers.

One of the main advantages of accumulations research is that it can be applied to both site-based and landscape studies. Studies of the Lower and Middle British Palaeolithic have adopted this approach, using both biface and levallois densities from well-mapped river terrace sequences to examine changing population at a regional scale (Ashton and Hosfield 2010; Ashton and Lewis 2001; Hosfield 1999, 2005). Artefact densities were calculated per square kilometre/100 000 years and adjusted to take into account biasing factors including differential rates of quarrying and urban growth across the different terrace areas. The most recent analysis, focusing on the Solent River system, postulates population peaks between Marine Isotope Stage [MIS] 12 and 10, followed by a decline during MIS 9 and 8 (Ashton and Hosfield 2010). The application of accumulations research to the Middle Pleistocene archaeological record has been particularly profitable, demonstrating how long-term demographic patterns can be extracted from coarse-grained palimpsest datasets in secondary deposits, although 
the re-working of artefacts from higher to lower deposits is a significant problem which can potentially skew the demographic signature (Ashton and Hosfield 2010).

Accumulations research has also been applied to site-based studies, exploring regional population trends in the Middle and Upper Palaeolithic. Meignen et al. (2006) compared the lithic artefact densities $/ \mathrm{m}^{3}$ of deposit, adjusted for the estimated length of occupation, at an early Middle Palaeolithic site (Hayonim Cave, Level F and base E) and a Late Middle Palaeolithic site (Kebara cave, units XI-IX) in the Levant, suggesting, based on both increased artefact densities and an increase in site numbers, population increase across the Middle Palaeolithic in the region. Increases in quantities of lithic artefacts have also been used to argue for population increase across the European Middle-Upper Palaeolithic transition in both Southwestern France (Mellars and French 2011, 2013) and the Swabian Jura, Southwestern Germany (Conard et al. 2012), although in the latter case, the study did not take into account the different lengths of the chronological phases in question. Adjusting for the length of phases, Mellars and French (2011) documented a mean of 9.7 retouched tools $/ \mathrm{m}^{2} / 1000$ years for the final Neanderthal (Châtelperronian) in Southwestern France contrasting with a mean of 17.6 retouched tools $/ \mathrm{m}^{2} / 1000$ years for the initial AMH (Aurignacian) occupation.

The main difficulties with accumulations research are well documented and not restricted to their application to Palaeolithic contexts. Most crucial is the nature of the relationship between the two variables. While the logic of a relationship between the number of people and the amount of occupation residue is sound, the specifics are ambiguous, and while most studies assume a linear relationship between the two variables (e.g. Kohler and Blinman 1987; Marsden and West 1992) this assumption is largely untested. Furthermore, the number of people is not the only variable which affects the amount of material discarded; factors such as the length of occupation affect the amount of material that are incorporated into the archaeological record. For example, Moncel and Rivals (2011) have used lithic material density at sites as part of their study into the length of Neanderthal occupations and overall mobility strategies (see also Sullivan 1992).

The palimpsest nature of most Palaeolithic deposits means that distinguishing individual episodes of occupation is usually impossible, and accumulations research is often used in Palaeolithic contexts as a measure of 'occupation intensity' where inter-site differences in the amount of cultural material are interpreted in terms of either varying population or varying occupation lengths/frequencies with low densities of material associated with short (or rare) occupations and high densities with long (or frequent) occupations (e.g. Conard et al. 2012). One way to choose between these competing explanations is to examine the evidence from other demographic proxies. For example, Mellars and French (2011) demonstrate that the increase in lithic density at sites in Southwestern France across the Middle-Upper Palaeolithic transition is accompanied by a similar increase in the numbers of sites, suggesting that decreased logistical mobility amongst AMHs cannot explain the increase seen in lithic densities (see also Ross 1985:87). Other forms of evidence for chronological differences in mobility and settlement strategies can be examined, and their impact on any estimates of lithic artefact densities assessed, including the ratio of local: non local lithic material, frequency of artefact retouch and prevalence of cortex found at the sites being studied (Amick 1996; Barton et al. 2011; Close 2000; Kelly and Todd 1988; Moncel and Rivals 2011; Riel-Salvatore and Barton 2004; Roth 2000; Sellet 2006; Surovell 2009; Thacker 2006). 
At a more fundamental level, questions still exist as how best to conduct accumulations research. While researchers have used both volume and area to quantify rates of accumulation, a frequent lack of knowledge of rates of sedimentation (e.g. rock falls) and erosion both within and between sites plagues the use of volume to calculate artefact densities. The question also remains as to what type of occupation residue should be examined. Accumulations research was developed using ceramics (e.g. Cook 1972); an artefact type which cannot be modified and reworked to the same extent as the lithic technology which dominates the Palaeolithic archaeological record (Dibble 1984; Rolland and Dibble 1990; Schott 1989). Differential degrees of retouching of lithic artefacts will affect their quantities in the archaeological record, independent of differences in the number of individuals using and manufacturing them. Furthermore, within the broad category of lithic artefacts, decisions still need to be made as to what types of artefacts to quantify. Due to lack of systematic excavation and collection of all but the most diagnostic and recognisable forms until the latter half of the $20^{\text {th }}$ century, researchers have typically limited their analysis to bifaces (Ashton and Hosfield 2010; Ashton and Lewis 2001; Hosfield 1999, 2005) or formal retouched tool classes (French 2013; Mellars and French 2011, 2013), ignoring unretouched elements such as flakes which were undoubtedly also used by people in the past (see Holdaway and Douglass 2012). Conard et al. (2012) found that lithic densities calculated using all remains, including microdebitage, were artificially inflated for those sites which were recently excavated due to improvements in excavation and recovery strategy, skewing the demographic signature. When only pieces $\geq 2 \mathrm{~cm}$ were analysed the values for these sites were comparable to the others in their study region of the Swabian Jura, Southwestern Germany (Conard et al. 2012: 240). In addition, several behavioural variables affect the quantity of lithic artefacts found in assemblages independent of population, including changes in artefact use and function, changes in location of discard and the effects of variable raw material supplies on manufacture, use and discard (see Attenbrow 2006: 28-29). Data on these variables are often lacking, and further than recognising them as a potential source of bias, their impact is difficult to assess (see French 2013).

Furthermore, lithic artefacts are just one (albeit the dominant) part of the Palaeolithic cultural repertoire. Organic remains are often poorly preserved in Palaeolithic contexts and similar quantitative data on other cultural material, including burnt bone and charcoal is thus frequently lacking (Conard et al. 2012). Aided by the excellent preservation offered by the limestone-dominated caves and rock-shelters of Southwestern France, Mellars and French $(2011,2013)$ used quantities of ungulate remains (expressed as estimates of meat weight $(\mathrm{kg})$ and deemed to represent food debris; White 1953) as part of their analysis of occupation intensity across the Middle-Upper Palaeolithic transition in the region. While data were available from fewer sites, these results complemented those found in the analysis of retouched tools, with a mean meat-weight of $84.6 \mathrm{~kg} / \mathrm{m}^{2} / 1000$ years found at Neanderthal (Châtelperronian) sites and $152.8 \mathrm{~kg} / \mathrm{m}^{2} / 1000$ years found at AMH (Aurignacian) sites. However, similar to lithic artefacts, the use of faunal remains as a demographic proxy needs to accommodate numerous biasing factors, including variation in the intensity of exploitation and processing of carcasses, differences in body-part transportation and variations in the rate of storage of faunal remains.

\section{Indirect approaches}

Although reliant on proxy data, the above three methods are the most direct approaches available to study demographic patterns from the archaeological record. Due to some of the problems with their application and use, archaeologists have also employed indirect approaches, inferring population trends from the perceived 
cultural responses to population change. The advantage of the types of data employed in these indirect studies is that they are often ratio or proportion data, circumventing some of the effects of taphonomic bias (Surovell and Brantingham 2007:1876). However, extra inferential steps are required to move from the data to estimates of demographic trends (Kuhn 2012: 82). As all palaeodemographic evidence comes from proxy data, to aid the verification and the interpretation of results, it is particularly important to compare any patterns generated from indirect data on cultural responses to those seen in other lines of evidence.

The use of indirect approaches in Palaeolithic contexts has focused on the relationship between hunter-gatherer populations and their environment and resource base. These studies draw on the much-cited, but difficult to calculate, factor of environmental carrying capacity ("the maximum population that a given region can sustain, if one assumes that a particular set of resources are being exploited with a given technology" ; Glassow 1978:39) (see Bayliss-Smith 1978; Brush 1975; Dewar 1984; Hassan 1978; Hayden 1975; Jochim 1976; Zubrow 1971, 1975), as well as elements of HBE, particularly optimal foraging theory (Belovsky 1988; Smith 1983). The most prominent example of this approach is that of Stiner and colleagues (Stiner 2001, 2009; Stiner and Munro 2002; Stiner et al. 1999, 2000, 2008 see also Munro and Atici 2009), who, in a series of papers, argue that changing patterns in the use of small game by hunter-gatherers act as a 'demographic barometer' (Stiner et al. 1999:193) for changes in human population density. Predator-prey dynamics between humans and small game mean that changes in human population density influence both the rates of contact between humans and their prey, and the availability of small game as a food resource. Stiner and colleagues ranked small prey according to handling costs and their resilience to over-harvesting by humans. The relative ratios of high-ranked tortoises (easy to catch but with populations sensitive to predation) to low-ranked partridges and hares (fast and difficult to catch, but resilient to human predation) in a faunal assemblage reflect changing human population density. A greater reliance on slow-moving species is only sustainable under conditions of low and dispersed populations, with an increase in the exploitation of fast-moving species reflecting increasing population densities, as the need to meet protein requirements forced foragers to broaden their diet to include species with high handling costs. Increased diversity of small game assemblages has been used to argue for increases in population density from the Middle to Upper Palaeolithic in Italy, Israel and Turkey (Stiner 2001, 2009; Stiner et al. 1999, 2000, 2008), as well as population decreases within the Natufian period (13-10 kya BP) in the Levant associated with the onset of the Younger Dryas (Stiner and Munro 2002).

Stiner and colleagues argue that changing proportions of small game in faunal assemblages provides a much better indicator of changes in human population density than similar data on large ungulates, as small species vary more in their population resilience and predator avoidance characteristics, as well as having similar body sizes making estimates of dietary yield more comparable (Stiner et al. 1999:190, 2000:56, 2008). Nonetheless, ungulates constituted the bulk of the diet of most Palaeolithic hunter-gatherers, and their relative abundance would also have affected human population densities, even if this exact impact is difficult to quantify. Drawing upon earlier ideas of a 'Broad Spectrum Revolution' (Binford 1968; Flannery 1969) which saw hunter-gatherers diversify their resource base during the late Pleistocene as a possible response to population growth, Marín Arroyo (2009) used a mathematical model to simulate the interaction between humans and four ungulate species during the Magdalenian in Northern Spain. Taking into account human foraging behaviour and topography, Marín-Arroyo concluded that the dietary diversification seen in the archaeological record was best explained by 
an increase in human population density rather than climatically-induced changes in resource availability. However, these two variables are often difficult to differentiate. In his study of the Middle-Upper Palaeolithic transition in Southwestern France, Morin (2008) argued that climatically-induced reduction in species diversity in the Early Upper Palaeolithic (Aurignacian), seen in the faunal assemblage at the site of Saint-Césaire, would have triggered declines in human population densities in the region. Within this decreased diversity, the increased reliance on reindeer, a famously fluctuating resource in terms of seasonal availability, would have exacerbated this decrease in population density. However, while the proposed link between hunter-gatherer population density and species diversity of the resource base is based on ethnographic data, the relevance of patterns seen in the continental North American ethnographic examples to the coastal-influenced landscape of late-glacial Southwestern France is not examined. Furthermore, Morin provides no additional independent evidence for population decrease in the Aurignacian, and it is questionable how far results based on the analysis of a single site can be extrapolated to regional population density estimates.

Taking data on assemblage composition and diversity one step further, Discamps (2013) produced environmental carrying capacity estimates for the Middle and Early Upper Palaeolithic of Southwestern France applying an ungulate biomass index to archaeozoological assemblages. Chronological variations in the ungulate biomass index (calculated through comparing the abundance of steppic taxa (Bison, Horse) with forest and tundra taxa (Red deer, Roe deer, Reindeer) were compared to the number and distribution of hyena dens to assess the impact of ungulate biomass fluctuations on large predators, with a close correlation seen between low periods of ungulate biomass and reduced hyena populations, and vice-versa. The number and distribution of hyena dens as a proxy for hyena population size is not hampered by the potential impact of shifting mobility and land-use strategies seen in the use of site counts as a proxy for human populations. The correspondence between the population of this large predator and reconstructed environmental carrying capacity suggests that prey availability was a key factor for the Neanderthal and AMH populations which also inhabited the region during this period. Based on ungulate biomass estimates by Delpech (1999), Langlais et al. (2012), have argued for a similar correlation between increased resource availability and increases in hunter-gatherer population density during the Middle Magdalenian (18-16 kya) in the same region.

The size of faunal remains has also been used to infer relative changes in Palaeolithic human population density. Decreases in the size of individuals of a given species are argued to reflect increasing human population densities and more intensive exploitation of the species due to pressure on food resources, as human preferences for larger individuals during times of low resource pressure exert considerable impact on the size and sex structures of the remaining prey population (Klein and Cruz-Uribe 1983, 2000; Klein and Steele 2013; Stiner 1999; Stiner et al. 2000; Straus et al. 1981). Non-dietary aspects of faunal assemblages have also been used as a palaeodemographic proxy. At the cave site of Grotte XVI in Southwestern France, Grayson and Delpech (2003) used declining cave bear abundances across the Middle-Upper Palaeolithic transition to argue for increased human group size and/or occupation length as Early Upper Palaeolithic (Aurignacian) groups out-competed cave bears for occupation of the cave. While the authors reject extrapolation of this finding as evidence of increased population densities across the region, the hypothesis of increased group size at the site during the Early Upper Palaeolithic is supported by similar increases in average lithic and faunal assemblage sizes from nearby sites. 
By far the biggest difficulty of using faunal data as an indirect proxy for demography is demonstrating that any differences in species size and consumption by humans are independent of changes brought about by climate or environmental change (see discussions in Klein and Cruz-Uribe 1983; Stiner et al. 2000). One obvious way in which an environmental explanation could be discounted is if the data showed the opposite pattern than that predicted by ecology (e.g. Stiner 2001:6994). In addition, all archaeozoological assemblages are anthropogenic and any estimates of carrying capacity based on these are approximate. Many of the approaches discussed above also suffer from the same problem of equifinality which hampers other palaeodemographic methods. In their study of chronological variation in the ratio of high-ranked to low-ranked small game at the Natufian site of Hayonim Cave, Israel, Stiner and Munro (2002) were unable to distinguish between the competing explanations of changes in group size or changes in occupation length, instead referring to changes in "site occupation intensity" defined as a combination of group size, length of stay and frequency of site visits. Furthermore, the attribution of dietary diversity to increased population densities contradicts the nutritional ecology model discussed earlier in which dietary diversification is a cause rather than a consequence of population growth (Hockett and Haws 2003, 2009), although this could be a result of the latter model's consideration of plant, as well as faunal, resources. Nonetheless, the relationship between food resources and hunter-gatherer demography provides a theoretically firm, if often difficult to quantify, avenue of research into Palaeolithic populations.

\section{Lessons from hunter-gatherer ethnography}

Finally, it is worth considering how, and to what extent, data on the demography of ethnographic huntergatherers can contribute to the study of Palaeolithic populations. There is a degree of circularity in the use of ethnography analogy to interpret and verify population trends seen in the archaeological record, as the results derive from the use of the methods described above, the assumptions of which were conceived largely on the basis of ethnographic data (e.g. Naroll 1962). Nonetheless, the search for cross-cultural demographic patterns amongst ethnographic hunter-gatherers can potentially help Palaeolithic archaeologists interpret the results generated from palaeodemographic methods, and to formulate hypotheses against which to test their data. Concerns about the uncritical application of data derived from modern foragers to the interpretation of prehistoric foragers are well-known, particularly those which highlight the contrast between the marginal environments and global contexts in which modern foragers live, and the Palaeolithic 'world of huntergatherers' (Freeman 1968; Kelly 2013: Chapter 10; Wobst 1978; Wylie 1985). There are undoubtedly differences between Pleistocene and post-Pleistocene hunter-gatherers (Foley 1988), and it is clearly both difficult and fundamentally flawed to attempt to establish a proto-type from any ethnographic group as a model of Pleistocene foragers. However, it is arguably equally flawed to ignore the structural basis of hunter-gatherer population dynamics as documented through cross-cultural analysis, particularly in view of the uniformitarian nature of demographic processes. Nonetheless, the use of ethnographic data as an interpretive tool to aid Palaeolithic demography is less suited to the archaeological records of pre-modern hominins, due to the effect of potential life history differences on fertility and mortality (Robson and Wood 2008).

As with archaeological populations, data on specific demographic parameters amongst ethnographic huntergatherers are rare (e.g. Blurton-Jones et al. 1992, 2002; Headland 1989; Helle and Helama 2007; Hill and Hurtado 1996; Hill et al. 2007; Howell 1979; Yengoyon 1972) and are biased towards those which have an clear socio-cultural component (e.g. childhood mortality and infanticide practices and mobility; Acker et al. 1975; 
Denham 1974; Divale 1972; Hayden 1972; Kelly 1992; Morales 1987; Schrire and Steiger 1974). The ability of the ethnographer to obtain demographic information is hampered by factors including cultural restrictions on informants which prevent individuals accurately answering questions, the lack of equivalent translations for demographic terms in native languages, and difficulties of estimating the ages of people who do not recognise time by the calendar year (Blurton Jones et al. 1992:164; Kelly 2013:167; Turnbull 1972:284). Nonetheless, the available data on specific demographic characteristics permit a sense of the range of variation found across hunter-gatherer groups (Kelly 2013: Chapter 7). Data on total fertility rate (the average number of births women who survive the reproductive span will bear) suggest a wide range of fertility rates amongst foragers, ranging between 2.6 and 8.0 (Kelly 2013: Table 7.5; Pennington 2001:195). Life expectancy at birth is also wideranging, from 37 years among the Ache of Paraguay to 21-24 years among the Agta of the Phillippines (Gurven and Kaplan 2007; Pennington 2001:194). Projecting simulations by Pennington (2001) based on the observed range of ethnographic forager fertility and survival rates to the past suggest that periods of rapid growth and decline would have characterised prehistoric hunter-gatherer populations. However, with small sample sizes and limited data, understanding the causes behind demographic variation remains difficult, particularly with regard to those, largely environmental, variables that archaeologists hope to address. One notable exception is the work of Helle and colleagues (Helle and Helama 2007; Helle et al. 2008) who examined the impact of temperature change of the population dynamics of three Sami groups in Northern Finland for the period 1722-1850 AD. Contrary to expectations, they demonstrated that variations in annual mean temperatures had no significant impact on birth and mortality rates (Helle and Helama 2007), although it possibly affected the birth sex ratio (Helle et al. 2008).

In order to grapple with the issue of relative population change amongst Palaeolithic foragers it is more useful to consider the outcome of variation in these demographic processes; group size and population density. Group size and population density are the best studied aspects of hunter-gatherer demography, on which a large corpus of quantitative, cross-cultural data are available. A full review of these parameters is outside the scope of this paper (see Binford 2001; Johnson 2014; Kelly 2013, Chapter 7) and the focus here will be summarising the relationship(s) between hunter-gatherer group sizes, population densities, and archaeologically discernible cultural and environmental variables.

Three nested types of hunter-gatherer groups are widely recognised: the family group, the local group/band and the regional group/tribe. Attempts to quantify the number of individuals which comprise these units have traditionally focused on the 'magic numbers' of 25 people in a local group and 500 in a regional group/tribe (Birdsell 1953, 1958, 1968, 1970; Lee and DeVore 1968; Martin 1973; Wilmsen 1973). Computer simulations by Wobst $(1974,1976)$ suggest a regional group size of 175-475 individuals as the minimum viable human breeding population size for hunter-gatherers; an estimate close to the 'magic number' of 500. Recent crosscultural studies also suggest average hunter-gatherer local group sizes of 28-30 people (Hill et al.2011; Marlowe 2005), as well as a scaling ratio of approximately 4 in the sizes of the nested levels of hunter-gatherer group types (Hamilton et al. 2007b). Nonetheless, the validity of these magic numbers as group size estimates should not be assumed in all contexts, particularly as they are likely influenced by different factors, with local group size related to resource availability and procurement roles and the regional group size related to reproductive strategies. The most comprehensive study of cross-cultural patterns of hunter-gatherer group sizes 
(Binford 2001), demonstrates variation based on a wide range of interacting variables. Binford's Group 1 (local group) and Group 2 (regional group) will be the focus of discussion here.

According to Binford (2001:229) mobility costs act as the ultimate limiting factor on hunter-gatherer group sizes. This relates to food availability and assumes that in the absence of intensification, the larger the group, the greater the demand on the food supply. The larger the group, the greater the number of moves needed per year to meet subsistence needs (Binford 2001:234; Kelly 2003:52). Group sizes are overall larger amongst sedentary or logistically mobile hunter-gatherers than those who are residentially mobile. However, the impact of mobility on group size is not straightforward and also depends on the group's subsistence base and the aspect of mobility being measured (see also Grove 2009). For example, groups primarily exploiting terrestrial animal resources move greater residential distances annually and make a greater number of residential moves than those reliant on plant or aquatic resources (Binford 2001:275). Binford (2001:278) suggests a threshold of $400 \mathrm{~km} / \mathrm{annum}$ travelled, below which groups making residential moves reduce their local group size with annual distance moved, and above which local group size increases.

While mobility is difficult to measure archaeologically, this variable interacts with those that are more discernible from the archaeological record, including diet. Group sizes are generally largest amongst foragers primarily dependent on terrestrial animal resources and smallest for those with a plant-based diet. The relative frequency of different group sizes also varies between subsistence bases, with plant-based groups associated most often with small local group sizes, and larger local group sizes more common amongst groups dependent on aquatic or animal resources (Binford 2001:252-3). As resource availability is strongly conditioned by the environment, differences in the effective temperature [ET] and environmental productivity (primary biomass) of the region also impact group size. Local group size and effective temperature are positively correlated up to a threshold of $11.53^{\circ} \mathrm{C}$ (latitudes above $35^{\circ}$ ) after which group size decreases as the ET drops (Binford 2001:263). There is also a trend towards larger group sizes as net above-ground productivity increases. This trend varies depending on the primary food source of the group, with the local group sizes of hunter-gatherers following a plant-based diet more strongly correlated with environmental productivity than those reliant on aquatic or animal resources (Binford 2001:265). Local group sizes are also largest amongst groups heavily dependent on food storage (Binford 2001:261), and other factors that are difficult to ascertain from the archaeological record, including division of labour, extent of polygny, and ranking are also shown by Binford to impact on group size.

At a wider scale of analysis, the combined population of these local groups is used to calculate the regional population density. Since Birdsell's $(1953,1958,1968)$ pioneering studies of Australian aboriginal populations it is widely accepted that hunter-gatherer population density is heavily determined by environmental factors, particularly as they relate to food availability (Belovsky 1988; Hassan 1981:7). Population density varies according to habitat type, with the highest density seen in temperate and tropical coastal environments, and the lowest in semi-desert and Arctic environments (Layton and O'Hara 2010). Marlowe (2005) has shown a correlation between population density and environmental productivity (expressed as primary biomass; $\mathrm{kg} / \mathrm{m}^{2}$ ), which levels off at a primary biomass of $\sim 30 \mathrm{~kg} / \mathrm{m}^{2}$. As habitat type and environmental productivity condition the available food resources, there is a clear relationship between hunter-gatherer population density and subsistence base, with the lowest population densities found amongst groups primarily dependent on terrestrial animal resources, and the highest amongst those focusing on aquatic resources (Binford 2001:380-383). 
However, population density can also affect the subsistence base exploited. For example, as population density increases, dependence on terrestrial animals decreases to the extent where no documented groups living at densities greater than 9.1 persons $/ 100 \mathrm{~km}^{2}$ are primarily dependent on animal resources (Binford 2001: 381). Hunter-gatherer population density also varies with mobility strategy, so that, regardless of subsistence base, logistically mobile and sedentary groups live in higher population densities than residentially mobile groups, with the population density threshold of 32-35 persons $/ 100 \mathrm{~km}^{2}$ between the two strategies (Binford 2001: 313). Total distance moved annually and average distance per residential move are also inversely correlated with population density (Binford 2001:312).

Cross-cultural patterns in hunter-gatherer group size and population density can aid archaeologists by providing a series of expectations about how these demographic variables change under different environmental conditions and subsistence strategies. However, the relationships between group size and population density, and the interacting variables affecting them, are complex and difficult to untangle. The relationship between mobility and demography is particular complicated, especially as it is often unclear which is the dependent and the independent variable. Both demography and mobility are affected by changes in environment and subsistence base. Amongst hunter-gatherers, mobility is often seen as a response to changing resource availability and distribution (Halstead and O'Shea 1989; Low 1990:236-8), with demographic change a likely result of resource fluctuations. The nature of ethnographic data on demography can also cause problems for archaeologists. This relates to the small scale of hunter-gatherer societies and the short time perspective enforced by the limits of ethnographic fieldwork. The small scale of forager societies means that they are highly subject to annual population fluctuations through stochastic error (Headland 1989:62). Furthermore, forager societies are characterised by annual and seasonal variations in population cohesion and dispersal ('fission-fusion'; Aureli et al. 2008; Harpending and Davies 1977; Layton and O'Hara 2010; Lee 1976; Mauss and Beuchat 1906). This constant state of flux of all ethnographically documented hunter-gatherer populations (Turnbull 1972: 289) precludes the assumption that any observed short-term demographic pattern is a reliable indicator of the population at any point other than the field work period. While anthropologists frequently adopt the use of stable population models to extrapolate longer-term population trends (e.g. Blurton Jones et al. 1992; see Howell 1979), archaeologists applying these results to Palaeolithic data-sets need to consider both the accuracy of the ethnographic data, and the best way to link this short-term data to the long-term demographic trends extrapolated from the archaeological record.

\section{Conclusion: The future of Palaeolithic demography}

The demography of Palaeolithic populations has been described as "one of the most critical and elusive of archaeological signatures" (Pike-Tay 2000:65). A society's demographic parameters affect other aspects of its peoples' lives (Cox 1976:2; Poston and Bouvier 2010; Weeks 1999:6-7), and an understanding of prehistoric demography is crucial to the understanding of the societal and artefactual change which dominates archaeological research agendas. Aided by results from genetics and computer modelling, Palaeolithic archaeologists are increasingly recognising the importance of demographic change, both to the lives of the individuals they study, and to the formation of the resultant archaeological record. Within evolutionary frameworks of HBE and DIT, demographic change has been cited as a key variable in the understanding of such 
important palaeoanthropological questions as when and why modern behaviour emerged, and why technological innovations were so rare amongst Lower Palaeolithic populations.

Despite this, proper consideration of exactly how elusive the archaeological signature of Palaeolithic demography is has, until now, been limited. As Bocquet-Appel and Demars (2000b:552) remind us, there are two recurring problems with palaeodemography: the quality of the sampling of data is never sufficient, and the uniformitarian assumptions linking the data and demographic interpretation are always bold. These problems are heightened in the Palaeolithic. Nonetheless, as discussed in this review, there are several excellent examples of the application of palaeodemographic methods to Palaeolithic data-sets, ranging from the Lower Palaeolithic of the British Isles to the terminal Pleistocene in the USA, permitting an understanding of relative population fluctuations both chronologically and geographically. Furthermore, while demography may be elusive compared to other archaeological variables (e.g. diet), it is arguably less so than others, such as cognitive and linguistic changes, which have long been serious subjects of enquiry from Palaeolithic data.

There are still many difficulties with conducting palaeodemographic research with Palaeolithic archaeological data. Foremost among these is how to assess the success of any palaeodemographic endeavour. How can we tell if the reconstruction of relative demographic change is accurate? This is, of course, impossible without written records with which to compare our archaeological reconstructions. The adoption of a multi-proxy approach to Palaeolithic demography is one way in which the accuracy of results can be assessed. If multiple palaeodemographic proxies reveal the same trend, the validity of the trend is strengthened. However, difficulties arise when the proxies do not match up and other factors specific to the archaeological record in question (data availability, preservation at archaeological sites) must be evoked to assess which proxy is 'correct' (French 2013). Ethnographic data can also be used to assess the accuracy of demographic reconstructions from Palaeolithic data. Cross-cultural analysis shows strong patterning in both group size and population density in hunter-gatherer societies with regard to such archaeologically-discernible variables as environment and subsistence base. The extent to which any Palaeolithic data correlate or converge with the expected ethnographic pattern provides a solid starting point for assessing whether demographic change is a valid interpretation of the patterns seen in the proxy data.

Perhaps the most crucial development required for a greater understanding of Palaeolithic demography is an improved ability to differentiate between the competing explanations for changes seen in the data used as demographic proxies. There is often little data available on the long-term fluctuations of the behavioural variables cited as alternative explanations, and as such, the palaeodemographer is limited to inferences based on 'snap-shots' of behavioural differences seen across their study period and/or region. Improving this requires increased diachronic data on such variables as raw material economies, lithic reduction sequences, faunal acquisition strategies and site function. In particular, the complex inter-dependent relationship between huntergatherer group sizes, population density and mobility (Binford 2001; Grove 2009; Kelly 2003), highlights the critical importance of finding ways to disentangle and identify the impact of these variables on hunter-gatherer societies, and how best to study these from the archaeological record remains a priority for Palaeolithic palaeodemography. The improvement and further development of Palaeolithic palaeodemography thus relies on the combined efforts of archaeologists from various specialisms and the availability of those data not only 
integral to the methods discussed in this review, but also those relevant to those factors which complicate the automatic equation with changes in the proxy data with population change.

This review has focused largely on how archaeologists study demography for the Palaeolithic archaeological record, with an emphasis on using archaeological data to document relative long-term fluctuations in population size and density. As a result, little attention has been paid to the important question of why any documented demographic changes occurred, including whether any changes were the result of natural population increase/decrease or migration. While understanding the reasons behind population change is the ultimate aim of palaodemography, if archaeologists want to continue to use demography as an explanatory concept in the Palaeolithic, they need first to engage more with the potential of their own data for palaeodemographic research, making increased effort to address the methodological challenges discussed in this paper.

\section{Acknowledgements}

Funding for this research was provided by an Arts and Humanities Research Council (UK) Doctoral Studentship and a Peterhouse (University of Cambridge, UK) Research Fellowship. Thanks to Paul Mellars, Robert Foley, Stephan Shennan, and Christina Collins for useful discussions of many of the ideas included in this paper, and Paul Mellars, Dominic Walker and two anonymous reviewers for helpful comments on earlier drafts of the manuscript.

\section{References}

Achilli, A., Rengo, C., Magri, C., Battaglia, V., Olivieri, S., Scozzari, R., Cruciani, F., Zeviani, M., Briem, E., Carelli, V., Moral, P., Dugoujon, J.-M., Roostalu, U., Loogväli, E.-L., Kivisild, T., Bandelt, H.-J., Richards, M., Villems, R., Santachiara-Benerecetti, A.S.,Semino, O., and Torroni, A. (2005). The molecular dissection of mtDNA haplogroup confirms that the Franco-Cantabrian glacial refuge was a major source for the European gene pool. American Journal of Human Genetics 75: 910-918.

Acker, C.L., Townsend, P.K., Schrire, C. and Steiger, W.L. (1975). Demographic models and female infanticide. Man 10 (3): 469-472.

Aiello, L.C., and Dunbar, R.I.M. (1993). Neocortex size, group size, and the evolution of language. Current Anthropology 34 (2): 184-193.

Aiello, L.C., and Wheeler, P. (2003). Neanderthal thermoregulation and the glacial climate. In van Andel, T.H., and Davies, W. (eds.), Neanderthals and Modern Humans in the European Landscape During the Last Glaciation: Archaeological Results of the Stage 3 Project, McDonald Institute Monographs, Cambridge, pp. 147-166.

Ambrose, S.H. (1998). Late Pleistocene human population bottlenecks, volcanic winter, and differentiation of modern humans. Journal of Human Evolution 34: 623-651.

Amick, D.S. (1996). Regional patterns of Folsom mobility and land use in the American Southwest. World Archaeology 27 (3): 411-426.

Ammerman, A.J., Cavalli-Sforza, L.L., and Wagener, D.K. (1976). Towards the estimation of population growth in old world prehistory. In Zubrow E.B.W. (ed.), Demographic Anthropology, University of New Mexico Press, Albuquerque (NM), pp. 27-61.

Anderson, D.G., and Faught, M.K. (2000). Palaeoindian artefact distributions: evidence and implications. Antiquity 74: 507-513. 
Anderson, D.G., Goodyear, A.C., Kennett, J., and West, A. (2011). Multiple lines of evidence for possible human population decline/settlement reorganization during the early Younger Dryas. Quaternary International 242: 570-583.

Armit, I., Swindles, G.T., and Becker, K. (2013). From dates to demography in late prehistoric Ireland? Experimental approaches to the meta-analysis of large ${ }^{14} \mathrm{C}$ data-sets. Journal of Archaeological Science 40: $433-438$.

Ascher, R. (1959). A prehistoric population estimate using midden analysis and two population models. Southwestern Journal of Anthropology 15 (2): 168-178.

Ashton, N., and Hosfield, R. (2010). Mapping the human record in the British early Palaeolithic: evidence from the Solent river system. Journal of Quaternary Science 25 (5): 737-753.

Ashton, N., and Lewis, S. (2001). Deserted Britain: declining populations in the British late middle Pleistocene. Antiquity 76: 388-396.

Attenbrow, V. (2006). What's Changing: Population Size or Land-Use Patterns? The Archaeology of Upper Mangrove Creek, Sydney Basin (Terra Australis 21), Pandanus Books, Canberra.

Aureli, F., Shaffner, C., Boesch, C., Bearder, S., Call, J., Chapman, C., Connor, R., Di Fiore, A., Dunbar, R.I.M., Henzi, S., Holekamp, K., Korstjens, A.H., Layton, R., Lee, P.C., Lehmann, J., Manson, J., RamosFernández, H., Strier, G., and van Schaik, C.P. (2008). Fission-fusion dynamics. New research frameworks. Current Anthropology 49: 627-654.

Ballenger, J.A.M., and Mabry, J.B. (2011). Temporal frequency distributions of alluvium in the American Southwest: taphonomic, paleohydraulic, and demographic implications. Journal of Archaeological Science 38: $1314-1325$

Bamforth, D.B., and Finlay, N. 2008. Introduction: Archaeological approaches to lithic production skill and craft learning. Journal of Archaeological Method and Theory 15: 1-27.

Bamforth, D.B., and Grund, B. (2012). Radiocarbon calibration curves, summed probability distributions, and early Paleoindian population trends in North America. Journal of Archaeological Science 39: 1768-1774.

Barrientos, G., and Perez, S.I. (2005). Was there a population replacement during the late mid- Holocene in the southeastern pampas of Argentina? Archaeological evidence and paleoecological basis. Quaternary International 132: 95-105.

Barton, C.M., Riel-Salvatore, J., Anderies, J.M., and Popescu, G. (2011). Modelling human ecodynamics and biocultural interactions in the Late Pleistocene of Western Eurasia. Human Ecology 39 (6): 705-725.

Bayliss-Smith, T. (1978). Maximum populations and standard populations: the carrying capacity question. In Green, D.C., Haselgrove, C., and Spriggs, M. (eds.), Social Organisation and Settlement, British Archaeological Reports 47, Archeopress, Oxford, pp. 129-151.

Beaton, J.M. (1991). The importance of past population for prehistory. In Meehan, B., and White, N. (eds.) Hunter-Gatherer Demography Past and Present, Oceania Monographs 39, University of Sydney Press, Sydney, pp. 23-40.

Beaumont, M.A. (1999). Detecting population expansion and decline using microsatellites. Genetics 153: 2013 2029.

Belovsky, G.E. (1988). An optimal foraging-based model of hunter-gatherer population dynamics. Journal of Anthropological Archaeology 7: 329-372.

Bettinger, R.L., and Eerkens, J.W. (1999). Point typologies, social transmission and the introduction of bow and arrow technology in the Great Basin. American Antiquity 64: 231-242.

Binford, L.R. (1968). Post-Pleistocene adaptations. In Binford, S.R., and Binford, L.R. (eds.), New Perspectives in Archaeology, Aldine, Chicago (IL), pp. 313-341. 
Binford, L.R. (1980). Willow smoke and dogs' tails: Hunter-Gatherer settlement systems and archaeological site formation. American Antiquity 45 (1): 4-20.

Binford, L.R. (1989). Isolating the transition to cultural adaptations: an organisational approach. In Trinkaus, E. (ed.), The Emergence of Modern Humans: Biocultural Adaptations in the Later Pleistocene, Cambridge University Press, Cambridge, pp. 18-41.

Binford, L.R. (1991). When the going gets tough, the tough gets going: Nunamuit local groups, camping patterns and economic organisation. In Gamble, C.S., and Boismier, W.A. (eds.), Ethnoarchaeological Approaches to Mobile Campsites, International Monographs in Prehistory, Ann Arbour (MI), pp. 23-139.

Binford, L.R. (2001). Constructing Frames of Reference. University of California Press, Berkeley (CA).

Bird, C.F.M., and Frankel, D. (1991). Chronology and explanation in western Victoria and south-east South Australia. Archaeology in Oceania 26 (1): 1-16.

Bird, D.W., and O'Connell, J.F. (2006). Behavioural ecology and archaeology. Journal of Archaeological Research 14 (2): 143-188.

Birdsell, J. B. (1953). Some environmental and cultural factors influencing the structuring of Australian aboriginal populations. American Naturalist 87: 171-207.

Birdsell, J.B. (1958). On population structure in generalized hunting and collection populations. Evolution 12 (2): 189-205.

Birdsell, J.B. (1968). Some predictions for the Pleistocene based on equilibrium systems among recent huntergatherers. In Lee, R.B., and deVore, I. (eds.), Man the Hunter, Aldine, New York (NY), pp. 229-240.

Birdsell, J.B. (1970). Local group composition among the Australian aborigines: A critique of the evidence from fieldwork conducted since 1930. Current Anthropology 11 (2): 115-142.

Blackwell, P.G., and Buck, C.E. (2003). The late glacial human reoccupation of north-western Europe: new approaches to space-time modelling. Antiquity 77: 232-240.

Blockley, S.M. (2005). Two hiatuses in human bone radiocarbon dates in Britain (17 000-5000 cal BP). Antiquity 79: 505-513.

Blockley S.M., and Gamble C.S. (2012). Europe in the Younger Dryas: animal resources, settlement and funerary behaviour. In Eren, M.I (ed.), Hunter-Gatherer Behaviour. Human Response During the Younger Dryas, Left Coast Press, Walnut Creek (CA), pp. 179-194.

Blockley, S.P.E., Donahue, R.E., and Pollard, A.M. (2000). Radiocarbon calibration and late glacial occupation in northwest Europe. Antiquity 74: 112-121.

Blurton Jones, N.G., Smith, L.C., O’Connell, J.F., Hawkes, K., and Kamuzora, C.L. (1992). Demography of the Hadza, an increasing and high density population of savanna foragers. American Journal of Physical Anthropology 89: 159-181.

Blurton Jones, N.G., Hawkes, K., and O’Connell, J.F. (2002). Antiquity of postreproductive life: are there modern impacts on hunter-gatherer postreproductive life spans? American Journal of Human Biology 14: 184205.

Bocquet-Appel, J.- P. (2008a). Recent Advances in Paleodemography: Data, Techniques, Patterns, Springer, Dordrecht.

Bocquet-Appel, J.-P. (2008b). La Paléodémographie. 99, $99 \%$ de l'Histoire Démographie des Hommes ou la Démographie de la Préhistoire, Éditions Errance, Paris.

Bocquet-Appel, J.-P., and Degioanni, A. (2013). Neanderthal demographic estimates. Current Anthropology 54 (8): S202-S213. 
Bocquet-Appel, J.-P., and Demars, P.-Y. (2000a). Neanderthal contraction and modern human colonization of Europe. Antiquity 74: 544-552.

Bocquet-Appel, J.-P., and Demars, P.-Y. (2000b). Population kinetics in the Upper Palaeolithic of Western Europe. Journal of Archaeological Science 27 (7) : 551-570.

Bocquet-Appel, J.-P., and Masset, C. (1982). Farewell to palaeodemography. Journal of Human Evolution 11: 321-333.

Bocquet-Appel, J.-P., and Tuffreau, A. (2009). Technological responses of Neanderthals to macroclimatic variations (240,000-40,000 BP). Human Biology 81 (2-3): 287-307.

Bocquet-Appel, J.-P., Demars, P.-Y., Noiret, L., and Dobrowsky, D. (2005). Estimates of Upper Palaeolithic meta-populations size in Europe from archaeological data. Journal of Archaeological Science 32: 1656-1668.

Bocquet-Appel, J.-P., Naji, S., van der Linden, M., and Kozlowski, J.K. (2009). Detection of diffusion and contact zones of early farming in Europe from the space-time distribution of ${ }^{14} \mathrm{C}$ dates. Journal of Archaeological Science 36: 807-820.

Boone, J.L. (2002). Subsistence strategies and early human population history: an evolutionary ecological perspective. World Archaeology 34 (1):6-25.

Bordes, F., Rigaud, J.-P., and de Sonneville-Bordes, D. (1972). Des buts, problemes et limites de l'archéologie paléolithique. Quaternaria 16: 15-34.

Borgerhoff Mulder, M., and Schacht, R. (2012). Human Behavioural Ecology. In: eLS. John Wiley \& Sons, Ltd: Chichester. DOI: 10.1002/9780470015902.a0003671.pub2

Boserup, E. (1965 [2003]). The Conditions of Agricultural Growth. The Economics of Agrarian Change Under Population Pressure, Routledge, London.

Boyd, R., and Richerson, P.J. (1985). Culture and the Evolutionary Process, University of Chicago Press, Chicago (IL).

Boyd, R., and Richerson, P.J. (2005). Not By Genes Alone: How Culture Transformed Human Evolution, University of Chicago Press, Chicago (IL).

Briggs, A.W., Good, J.M., Green, R.E., Krause, J., Maricic, T., Stenzel, U., Lalueza-Fox, C., Rudan, P., Brajković, D., Kućan, Z., Gušic, I., Schmitz, R., Golovanova, V.B., de la Rasilla, M., Fortea, J., Rosas, A., and Pääbo, S. (2009). Targeted retrieval and analysis of five Neanderthal mtDNA genomes. Science 325: 318-321.

Bronson, B. (1975). The earliest farming: demography as cause and consequence. In Polgar, S. (ed.), Population, Ecology and Social Evolution, Aldine, Chicago (IL), pp. 53-79.

Brown, B.M. (1987). Population estimation from floor area: a restudy of "Naroll's Constant". Cross Cultural Research 21: 1-49.

Brumm, A., and Moore, M.W. (2005). Symbolic revolutions and the Australian archaeological record. Cambridge Archaeological Journal 15(2): 157-175.

Brush, S.B. (1975). The concept of carrying capacity for systems of shifting cultivation. American Anthropologist 77 (4): 799-811.

Buchanan, B., and Collard, M. (2007). Investigating the peopling of North American through cladistic analysis of Early Paleoindian projectile points. Journal of Anthropological Archaeology 26: 366-393.

Buchanan, B., Collard, M., and Edinborough, K. (2008). Paleoindian demography and the extraterrestrial impact hypothesis. Proceedings of the National Academy of Sciences USA 105 (33): 11651-11654.

Buck, L.T., and Stringer, C. B. (2013). Having the stomach for it: a contribution to Neanderthal diets?

Quaternary Science Reviews (2013), http://dx.doi.org/10.1016/j.quascirev.2013.09.003 
Buikstra, J.E., and Konigsberg, L.W. (1985). Paleodemography: critiques and controversies. American Anthropologist 87 (2): 316-333.

Buikstra, J.E., Konigsberg, L.W., Billington, J. (1986). Fertility and the development of agriculture in the prehistoric Midwest. American Antiquity 51: 528-546.

Burke, A. (2006). Neanderthal settlement patterns in Crimea: a landscape approach. Journal of Anthropological Archaeology 25: 510-523.

Caspari, R., and Lee, S.H. (2004). Older age becomes common late in human evolution. Proceedings of the National Academy of Sciences USA 101 (30): 10895-10900.

Caspari, R., and Lee, S.H. (2006). Is human longevity a consequence of cultural change or modern behaviour? American Journal of Physical Anthropology 129: 512-517.

Casselberry, S.E. (1974). Further refinement of formulae for determining population from floor area. World Archaeology 6 (1): 117-122.

Casteel, R.W. (1979). Relationships between surface area and population size: a cautionary note. American Antiquity 44 (4): 803-807.

Cavalli-Sforza, L.L., and Feldman, M.W. (1981). Cultural Transmission and Evolution: A Quantitative Approach, Princeton University Press, Princeton (NJ).

Chamberlain, A. (2006). Demography in Archaeology, Cambridge University Press, Cambridge.

Chamberlain, A. (2009). Archaeological Demography. Human Biology 81 (2-3): 275-286.

Chapman, J. (1999). Archaeological proxy data for demographic reconstructions: facts, factoids or fiction? In Bintliff, J., and Sbonais, K. (eds.), Reconstructing Past Population Trends in Mediterranean Europe (3000 BC$A D$ 1800), Oxbow Books, Oxford, pp. 65-76.

Childe, V.G. (1936 [1965]). Man Makes Himself (4 ${ }^{\text {th }}$ edition), Collins, London.

Childe, V.G. (1950). The Urban Revolution. Town Planning Review 21 (1): 3-17.

Churchill, S.E. (2006). Bioenergetic perspectives on Neanderthal thermoregulatory and activity budgets. In Harvarti, K., and Harrison, T. (eds.), Neanderthals Revisited: New Approaches and Perspectives, Springer, Dordrecht, pp. 113-134.

Close, A.E. (2000). Reconstructing movement in prehistory. Journal of Archaeological Method and Theory 7 (1): 49-77.

Cohen, M.N. (1975a). Population pressure and the origins of agriculture: an archaeological example from the coast of Peru. In Polgar, S. (ed.), Population, Ecology and Social Evolution, Aldine, Chicago (IL), pp. 79-121.

Cohen, M.N. (1975b). Archaeological evidence for population pressure in pre-agricultural societies. American Antiquity 40 (4):471-474.

Cohen, M.N. (1977). The Food Crisis in Prehistory: Overpopulation and the Origin of Agriculture, Yale University Press, New Haven (CT).

Collard, M., and Shennan, S. (2000). Processes of culture change in prehistory: a case study from the European Neolithic. In Renfrew, C., and Boyle, K. (eds.), Archaeogenetics: DNA and the Population Prehistory of Europe, McDonald Institute Monographs, Cambridge, pp. 89-97.

Collard, M., Kemery, M., and Banks, S. (2005). Causes of toolkit variation among hunter-gatherers: a test of four competing hypotheses. Canadian Journal of Archaeology 29, 1-19.

Collard, M., Buchanan, B., Morin, J., and Costopoulos, A. (2011). What drives the evolution of hunter-gatherer subsistence technology? A reanalysis of the risk hypothesis with data from the Pacific Northwest. Philosophical Transactions of the Royal Society B 366: 1129-1138. 
Collard, M., Buchanan, B., and O’Brien, M.J. (2013a). Population size as an explanation for patterns in the Paleolithic archaeological record: more caution is needed. Current Anthropology 54 (S8), S388-S396.

Collard, M., Buchanan, B., O’Brien, M.J., and Scholnick, J. (2013b). Risk, mobility or population size? Drivers of technological richness among contact-period western North American hunter-gatherers. Philosophical Transactions of the Royal Society B 368, 2012412 doi: http://dx.doi.org/10.1098/rstb.2012.0412.

Collard, M., Ruttle, A., Buchanan, B., and O'Brien, M.J. (2013c). Population size and cultural evolution in nonindustrial food-producing societies. PloS One 8(9): e72628. doi:10.1371/journal.pone.0072628.

Collins, C.M. (2012). Population Dynamics in the Late Glacial Refugium of Southwestern France, Unpublished $\mathrm{PhD}$ thesis, University of Sheffield, UK.

Conard, N.J. (2001). Advances and problems in the study of Palaeolithic settlement systems. In Conard, N.J. (ed.), Settlement Dynamics of the Middle Palaeolithic and Middle Stone Age, Kerns Verlag, Tübingen, pp. vii$\mathrm{xX}$.

Conard, N.J., Bolus, M., and Münzel, S.C. (2012). Middle Palaeolithic land use, spatial organization and settlement intensity in the Swabian Jura, southwestern Germany. Quaternary International 247, 236-245.

Conkey, M.W. (1987). Interpretive problems in hunter-gatherer regional studies. In Soffer, O. (ed.), The Pleistocene Old World: Regional Perspectives, Plenum Press, New York (NY), pp. 63-77.

Cook, S.F. (1946). A reconsideration of shellmounds with respect to population and nutrition. American Antiquity 12 (1): 50-53.

Cook, S.F. (1972). Can pottery residues be used as an index to population? Contributions of the University of California Archaeological Research Facility 14: 17-40.

Cook, S.F., and Heizer, R.F. (1968). Relationships among houses, settlement areas, and population in aboriginal California. In Chang, K.C. (ed.), Settlement Archaeology, National Press Books, Palalto (CA), pp. 79-116.

Corruccini, R.S., Brandon, E.M., and Hander, J.S. (1989). Inferring fertility from relative mortality in historically controlled remains from Barbados. American Antiquity 54: 609-614.

Cowgill, G.L. (1975a). On causes and consequences of ancient and modern population changes. American Anthropologist 77 (3): 505-525.

Cowgill, G.L. (1975b). Population pressure as a non-explanation. Memoirs of the Society for American Archaeology 30: 127-133.

Cox, P.R. (1976). Demography (5 ${ }^{\text {th }}$ edition), Cambridge University Press, Cambridge.

Crombé, P., and Robinson, E. (2014). ${ }^{14} \mathrm{C}$ dates as demographic proxies in Neolithisation models of northwestern Europe: a critical assessment using Belgium and northeast France as a case-study. Journal of Archaeological Science (In Press).

Culotta, E. (2010). Did modern humans get smart or just get together? Science 328, 164.

Curet, L.A. (1998). New formulae for estimating prehistoric populations for lowland South American and the Caribbean. Antiquity 72: 359-375.

d'Errico, F. (2003). The invisible frontier: a multiple species model for the origin of behavioural modernity. Evolutionary Anthropology 12: 188-202.

d'Errico, F., and Banks, W.E. (2013). Identifying mechanisms behind Middle Paleolithic and Middle Stone Age cultural trajectories. Current Anthropology 54 (S8): S371-S387. 
d'Errico, E., and Vanhearen, M. (2007). Evolution or revolution? New evidence for the origin of symbolic behaviour in and out of Africa. In Mellars, P., Boyle, K., Bar-Yosef, O., and Stringer, C. (eds.), Rethinking the Human Revolution, McDonald Institute Monographs, Cambridge, pp. 275-286.

d'Errico, F., Henshilwood, C.S., and Nilssen, P. (2001). An engraved bone fragment from ca. 75 kyr Middle Stone Age levels at Blombos Cave, South Africa : implications for the origin of symbolism. Antiquity 75 : 309318.

Daugherty, H.H., and Kammeyer, K.C.W. (1995). An Introduction to Population ( ${ }^{\text {nd }}$ Edition), The Guildford Press, New York (NY).

David, N. (1973). On Upper Palaeolithic society, ecology and technological change: the Noaillian case. In Renfrew, C. (ed.), The Explanation of Culture Change: Models in Prehistory, Duckworth, London, pp. 277303.

David, N. (1985). Excavation of the Abri Pataud, Les Eyzies (Dordogne). The Noaillian (Level 4) Assemblages and the Noaillian Culture in Western Europe, American School of Prehistoric Research Bulletin 37.

Davies, M.I.J. (2010). From platforms to people: rethinking population estimates for the abandoned agricultural settlement at Engaruka, northern Tanzania. Azania: Archaeological Research in Africa 45 (2): 203-213.

Delpech, F. (1999). Biomasse d'ongulés au Paléolithique et inferences sur la démographie. Paléo 11: 19-42.

Demars, P.-Y. (1996). Demographie et occupation de l'espace au Paléolithique supérieur et au Mesolithique en France. Préhistoire Européenne 8: 3-26.

Demars, P.-Y. (1998). Les rapports de l'homme et du mileu dans le nord de l'Aquitaine au Paléolithique supérieur l'implantation des habitats. Bulletin Préhistoire de Sud-Ouest 5: 13-30.

Denham, W.W. (1974). Population structure, infant transport, and infanticide among Pleistocene and modern hunter-gatherers. Journal of Anthropological Research 30 (3): 191-198.

Dennell, R.W., Martinón-Torres, M., and Bermúde de Castro, J.M. (2011). Hominin variability, climatic instability and population demography in Middle Pleistocene Europe. Quaternary Science Reviews 30: 15111524.

Derex, M., Beugin, M.-P., Godelle, B., and Raymond, M. (2013). Experimental evidence for the influence of group size on cultural complexity. Nature 503: 389-391.

DeRoche, C.D. (1983). Population estimates from settlement area and number of residences. Journal of Field Archaeology 10 (2): 187-192.

Dewar, R.E. (1984). Environmental productivity, population regulation and carrying capacity. American Anthropologist 86 (3): 601-614.

Dibble, H. L. (1984). Interpreting typological variation of Middle Palaeolithic scrapers: function, style or sequence of reduction? Journal of Field Archaeology 11: 431-436.

Discamps, E. (2013). Ungulate biomass fluctuations endured by Middle and Early Upper Palaeolithic societies (SW France, MIS 5-3): The contributions of modern analogs and cave hyena paleodemography. Quaternary International (In Press).

Divale, W.T. (1972). Systemic population control in the Middle and Upper Palaeolithic: inferences based on contemporary hunter-gatherers. World Archaeology 4 (2): 222-243.

Dogandžić, T., and McPherron, S.P. (2013). Demography and the demise of the Neanderthals: a comment on 'Tenfold Population Increase at the Neanderthal-to-Modern-Human Transition'. Journal of Human Evolution 64 (4): 311-313. 
Drucker, D., and Bocherons, H. (2004). Carbon and nitrogen stable isotopes as tracers of change in diet breadth during Middle and Upper Palaeolithic in Europe. Journal of Osteoarchaeology 14 (3-4): 162-177.

Dumond, D.E. (1965). Population growth and culture change. Southwestern Journal of Anthropology 21: 302324.

Dunnell, R.C. (1978). Style and function: a fundamental dichotomy. American Antiquity 43 (2): 192-202.

Dunnell, R.C. (1980). Evolutionary theory and archaeology. Advances in Archaeological Method and Theory 3: 35-99.

Edinborough, K. (2009). Population history and the evolution of Mesolithic arrowhead technology in Scandinavia. In Shennan, S. (ed.), Pattern and Process in Cultural Evolution, University of California Press, Berkley (CA), pp. 191-202.

Eerkens, J.W., and Lipo, C.P. (2005). Cultural transmission, copying errors, and the generation of variation in material culture in the archaeological record. Journal of Anthropological Archaeology 24: 316-334.

Eerkens, J.W., and Lipo, C.P. (2007). Cultural transmission theory and the archaeological record: providing context to understanding variation and temporal changes in material culture. Journal of Archaeological Research 15: 239-274.

Eerkens, J.W., Bettinger, R.L., and Richerson, P.J. (2013). Cultural transmission theory and hunter-gatherer archaeology. In Cummings, V., Jordan, P., and Zvelebil, M. (eds.), The Oxford Handbook of the Archaeology and Anthropology of Hunter-Gatherers, Oxford University Press, Oxford, pp. 1127-1142.

Excoffier, L. (2002). Human demographic history: refining the recent African origin model. Current Opinion in Genetics and Development 12: 675-682.

Excoffier, L., and Schneider, S. (1999). Why hunter-gatherer populations do not show signs of Pleistocene demographic expansions. Proceedings of the National Academy of Sciences USA 96: 10597-1602.

Fabre. V., Condemi, S., and Degioanni, A. (2009). Genetic evidence of geographical groups among Neanderthals. PloS One 4(4), e5151. doi:10.1371/journal.pone.0005151.

Fiedel, S.J., and Kuzmin, Y.-V. (2007). Radiocarbon date frequency as an index of intensity of Paleolithic occupation of Siberia: did humans react predictably to climate oscillations? Radiocarbon 49 (2): 741-756.

Fitzhugh, B., and Trusler, A.K. (2009). Case study in technological evolution: innovation and experimentation in and with the archaeological record. In Shennan, S. (ed.), Pattern and Process in Cultural Evolution, University of California Press, Berkeley (CA), pp. 203-223.

Flannery, K.V. (1969). Origins and ecological effects of early domestication in Iran and the Near East. In Ucko, P.J., and Dimbleby, G.W. (eds.), The Domestication and Exploitation of Plants and Animals, Duckworth, London, pp. 73-100.

Fletcher, R. (1981). People and space: A case study on material behaviour. In, Hodder, I., Isaac, G., and Hammond, N. (eds.), Patterns of the Past. Studies in Honour of David Clarke, Cambridge University Press, Cambridge, pp. 97-128.

Fletcher, R. (1991). Residential densities, group sizes and social stress in Australian aboriginal settlements. In Meehan, B., and White, N (eds.), Hunter-Gatherer Demography: Past and Present, Oceania Monographs 39, University of Sydney Press, Sydney, pp. 81-96.

Foley, R.A. (1988). Hominids, humans \& hunter-gatherers: an evolutionary perspective. In Ingold T., Riches D., and Woodburn, J. (eds.), Hunters and Gatherers 1: History, Evolution and Social Change, Berg, Oxford, pp. 207-221.

Freeman, L.G. (1968). A theoretical framework for interpreting archaeological materials. In Lee, R.B., and deVore, I. (eds.), Man The Hunter, Aldine, Chicago (IL), pp. 262-7. 
French, J.C. (2013). Populating the Palaeolithic: A Palaeodemographic Analysis of the Upper Palaeolithic Hunter-Gatherers of Southwestern France, Unpublished PhD thesis, University of Cambridge, UK.

Freter, A.C. (1997). The question of time: the impact of chronology on Copán prehistoric settlement demography. In Paine, R.R. (ed.), Integrating Archaeological Demography: Multidisciplinary Approaches to Prehistoric Population, Southern Illinois University at Carbondale, Center for Archaeological Investigations: Occasional Paper No.24. pp, 21-42.

Fritz, J.M. (1972). Archaeological systems for indirect observation of the past. In Leone, M.P. (ed.), Contemporary Archaeology: A Guide to Theory and Contributions, Southern Illinois University Press, Illinois (IL), pp. 135-157.

Froehle, A.W., and Schoeninger, M.J. (2008). Intraspecies variation in BMR does doe affect estimates of early hominin total daily energy expenditure. American Journal of Physical Anthropology 131: 552-559.

Gallivan, M.D. (2002). Measuring sedentariness and settlement population: accumulations research in the Middle Atlantic region. American Antiquity 67 (3): 535-557.

Gamble, C., Davies, W., Pettitt, P., and Richards, M. (2004). Climate change and evolving human diversity in Europe during the last glacial. Philosophical Transactions of the Royal Society B 359: 243-254.

Gamble, C., Davies, W., Pettitt, P., Hazelwood, L., and Richards, M. (2005). The archaeological and genetic foundations of the European population during the Late Glacial: implications for 'agricultural thinking'. Cambridge Archaeological Journal 15 (2): 193-223.

Garrigan, D., Kingan, S.B., Pilkington, M.M., Wilder, J.A., Cox, M.P., Soodyall, H., Strassmann, B., DestroBisol, G., de Knijff, P., Novelltto, A., Friedlaender, J., and Hammer, M.F. (2007). Inferring human population sizes, divergence times and rates of gene flow from mitochrondrial, $\mathrm{X}$ and $\mathrm{Y}$ chromosome resequencing data. Genetics 177 : 2195-2207.

Ghirlanda, S., and Enquist, M. (2007). Cumulative culture and explosive demographic transitions. Quality and Quantity 41: 591-600.

Ghirlanda, S., Enquist, M. and Perc, M. (2010). Sustainability of culture-driven population dynamics. Theoretical Population Biology 77: 181-188.

Gilpin, M.E., and Soulé, M.E. (1986). Minimum viable populations: processes of species extinction. In, Soulé, M.E (ed.), Conservation Biology: The Science of Scarcity and Diversity, Sinauer Associates, Sunderland (MA), pp. 19-34.

Glassow, M.A. (1967). Considerations in the estimation of prehistoric Californian coastal populations. American Antiquity 32: 354-359.

Glassow, M.A. (1978). The concept of carrying capacity in the study of culture process. Advances in Archaeological Method and Theory 1: 31-47.

Gould, R.A, and Yellen, J.E. (1987). Man the hunted: Determinants of household spacing in desert and tropical foraging societies. Journal of Anthropological Archaeology 6: 77-103.

Graf, K.E. (2009). "The good, the bad, and the ugly": evaluating the radiocarbon chronology of the middle and late Upper Paleolithic in the Enisei River valley, south-central Siberia. Journal of Archaeological Science 36: 694-707.

Grayson, D.K., and Delpech, F. (2003). Ungulates and the Middle-to-Upper Paleolithic transition at Grotte XVI (Dordogne, France). Journal of Archaeological Science 30 (12): 1633-1648.

Green, R.E., Krause, J., Ptak, S.E., Briggs, A.W., Ronan, M.T., Simons, J.F., Du, L., Egholm, M., Rothberg, J.M., Paunovic, M., and Pääbo, S. (2006). Analysis of one million base pairs of Neanderthal DNA. Nature 444: 330-336. 
Green, R.E., Krause, J., Briggs, A.W., Maricic, T., Stenzel, U., Kircher, M., Patterson, N., Li, H., Zhai, W., Fritz, M.H.-Y., Hansen, N.F., Durand, E.Y., Malaspinas, A.-S., Jensen, J.D., Marques-Bonet, T., Alkan, C., Prüfer, K., Meyer, M., Burbano, H.A., Good, J.M., Schultz, R., Aximu-Petri, A., Butthof, A., Höber, B., Höffner, B., Siegemund, M., Weihmann, A., Nusbaum, C., Lander, E.S., Russ, C., Novod, N., Affourtit, J., Egholm, M., Verna, C., Rudan, P., Brajkovic, D., Kucan, Z., Gušic, I., Doronichev, V.B., Golovanova, L.V., Lalueza-Fox, C., de la Rasilla, M., Fortea, J., Rosas, A., Schmitz, R.W., Johnson, P.L.LF., Eichler, E.E., Falush, D., Birney, E., Mullikin, J.C., Slatkin, M., Nielsen, R., Kelso, J., Lachmann, M., Reich, D., and Pääbo, S. (2010). A draft sequence of the Neanderthal genome. Science 328: 710-722.

Greene, D.L., Van Gerven, D.P., and Armelagos, G.J. (1986). Life and death in ancient populations: bones of contention in Paleodemography. Human Evolution 1 (3): 193-207.

Grove, M. (2009). Hunter-gatherer movement patterns: causes and constraints. Journal of Anthropological Archaeology 28: 222-233.

Grove, M. (2010). The archaeology of group size. In Dunbar, R., Gamble, C., and Gowlett, J. (eds), Social Brain, Distributed Mind, Proceedings of the British Academy 158 pp. 391-411.

Grove, M. (2012). Scatters, patches and palimpsests: solving the contemporaneity problem. In Reubens, K., Romansowska, I., and Bynoe, R. (eds), Unravelling the Palaeolithic. Ten Years of Research at the Centre for the Archaeology of Human Origins (CAHO, University of Southampton), University of Southampton Series in Archaeology 8, Archeopress, Oxford, pp. 153-164.

Guatelli-Steinberg, D. (2009). Recent studies of dental development in Neanderthals: implications for Neanderthal life histories. Evolutionary Anthropology 18 (1): 9-20.

Gurven, M., and Kaplan, H. (2007). Longevity among hunter-gatherers: a cross-cultural examination. Population and Development Review 33 (2): 321-365.

Halstead P., and O'Shea, J. (1989). Introduction: Cultural responses to risk and uncertainty. In Halstead P., and O’Shea, J. (eds), Bad Year Economics. Cultural Responses to Risk and Uncertainty, Cambridge University Press, Cambridge, pp. 1-8.

Hammel, E.A., and Howell, N. (1987). Research into population and culture: an evolutionary framework (and comments and replies). Current Anthropology 28 (2):141-160.

Hardy, B.L. (2010). Climatic variability and plant food distribution in Pleistocene Europe: implications for Neanderthal diet and subsistence. Quaternary Science Reviews 29 (5-6): 662-679.

Harner, M.J. (1970). Population pressure and the social evolution of agriculturalists. Southwestern Journal of Anthropology 26: 67-86.

Hamilton M.J., Milne, B.T., Walker, R.S., and Brown, J.H. (2007a). Nonlinear scaling of space use in human hunter-gatherers. Proceedings of the National Academy of Sciences USA 104 (11): 4765-4769.

Hamilton, M.J., Milne, B.T., Walker, R.S., Burger, O., and Brown, J.H. (2007b). The complex structure of hunter-gatherer social networks. Proceedings of the Royal Society B 274: 2195-2202.

Harpending, H., and Davis, H. (1977). Some implications for hunter-gatherer ecology derived from the spatial structure of resources. World Archaeology 8 (3): 275-286.

Hassan, F.A. (1974). Population growth and cultural evolution. Reviews in Anthropology 1: 205-212.

Hassan, F.A. (1975). Determination of the size, density and growth rate of hunting-gathering populations. In Polgar, S. (ed.), Population, Ecology, and Social Evolution, Aldine, Chicago (IL), pp. 27-53.

Hassan, F. A. (1978). Demographic archaeology. Advances in Archaeological Method and Theory 1: 49-103.

Hassan, F.A. (1979). Demography and Archaeology. Annual Review of Anthropology 8: 137-160. 
Hassan, F.A. (1981). Demographic Archaeology, Academic Press, New York (NY).

Haviland, W.A. (1969). A new population estimate for Tikal, Guatemala. American Antiquity 34 (4): 429-433.

Hawks, J. (2008). From genes to numbers: effective population sizes in human evolution. In Boquet-Appel, J.-P. (ed.), Recent Advances in Palaeodemography: Data, Techniques, Patterns, Springer, Dordrecht, pp. 9-30.

Hayden, B. (1972). Population control among hunter/gatherers. World Archaeology 4 (2): 205-221.

Hayden, B. (1975). The carrying capacity dilemma. American Antiquity 40, Memoir 30: 205-221.

Hayden, B. (2012). Neanderthal social structure? Oxford Journal of Archaeology 31 (1): 1-26.

Headland, T.N. (1989). Population decline in a Philippine Negrito hunter-gatherer society. American Journal of Human Biology 1: 59-72.

Heizer, R.F. (1960). Physical analysis of habitation residues. In Heizer, R.F., and Cook, S.F. (eds.), The Application of Quantitative Methods in Archaeology, Viking Fund Publications in Anthropology 28, pp. 93157.

Helle, S., and Helama, S. (2007). Climatic variability and the population dynamics of historical huntergatherers: the case of the Sami of Northern Finland. American Journal of Human Biology 19: 844-853.

Helle S., Helama S., and Jokela, J. (2008). Temperature-related birth sex ratio bias in historical Sami: warm years bring more sons. Biology Letters (2008) 4, 60-62.

Henrich, J. (2004). Demography and cultural evolution: how adaptive cultural processes can produce maladaptive losses: the Tasmanian case. American Antiquity 69 (2):197-214.

Henrich, J. (2006). Understanding cultural evolutionary models: a reply to Read's critique. American Antiquity $71(4): 771-782$.

Henry, A.G., Brooks, A.S., and Piperno, D.R. (2014). Plant foods and the dietary ecology of Neanderthals and early modern humans. Journal of Human Evolution 69: 44-54.

Henshilwood, C.S. (2007). Fully symbolic Sapiens behaviour: innovations in the Middle Stone Age at Blombos Cave, South Africa. In Mellars, P., Boyle, K., Bar-Yosef, O., and Stringer, C. (eds.), Rethinking the Human Revolution, McDonald Institute Monographs, Cambridge, pp. 123-132.

Henshilwood, C.S., and Marean, C.W. (2003). The origin of modern human behaviour: critique of the models and their test implications. Current Anthropology 44: 625-652.

Henshilwood, C.S., d'Errico, F., Vanhaeren, M., van Niekerk, K., and Jacobs, Z. (2004). Middle Stone Age shell beads from South Africa. Science 304 (5669): 404.

Higham, T.H. (2011). European Middle and Upper Palaeolithic radiocarbon dates are often older than they look: problems with previous dates and some remedies. Antiquity 85: 235-249.

Higham, T., Douka, K., Wood, R., Bronk Ramsey, C., Brock, F., Basell, L., Camps, M., Arrizabalaga, A., Baena, J., Barroso-Ruíz, C., Bergman, C., Boitard, C., Boscato, P., Caparrós, M., Conard, N.J., Draily, C., Froment, A., Galván, Gambassini, P., Garcia-Moreno, A., Grimaldi, S., Haesaerts, P., Holt, B., IriarteChiapusso, M-J., Jelinek, A., Jordá Pardo, J.F., Máillo-Fernández, J-M., Marom, A., Maroto, J., Menéndez, M., Metz, L., Morin, E., Moroni, A., Negrino, F., Panagopoulou, E., Peresani, M., Pirson, S., de la Rasilla, M., RielSalvatore, J., Ronchitelli, A., Santamaria, D., Semal, P., Slimak, L., Soler, J., Soler, N., Villaluenga, A., Pinhasi, R., and Jacobi, R. (2014). The timing and spatiotemporal patterning of Neanderthal disappearance. Nature 512: 306-309.

Hill, J.N. (1970). Broken K Pueblo: Prehistoric social organisation in the American Southwest, Anthropological Papers of the University of Arizona 18, The University of Arizona Press, Tucson (AZ).

Hill, K. (1993). Life history theory and evolutionary anthropology. Evolutionary Anthropology 2 (3): 78-88. 
Hill, K., and Hurtado, A.M. (1996). Ache Life History. The Ecology and Demography of a Foraging People, Aldine de Gruyter, New York (NY).

Hill, K., Hurtado, A.M., and Walker, R.S. (2007). High adult mortality among Hiwi hunter-gatherers: implications for human evolution. Journal of Human Evolution 52: 443-454.

Hill, K.R., Walker, R.S., Božičević, M., Eder, J., Headland, T., Hewlett, B., Magdalena Hurtado, A., Marlowe, F., Wiessner, P., and Wood, B. (2011). Co-residence patterns in hunter-gatherer societies show unique human social structure. Science 331: 1286-1289.

Hinde, A. (2002). Demographic perspectives on human population dynamics. In MacBeth, H., and Collinson, P. (eds.), Human Population Dynamics: Cross-disciplinary Perspectives, Cambridge University Press, Cambridge, pp. 17-40.

Hinz, M., Feeser, I., Sjögren, K-G., and Müller, J. (2012). Demography and the intensity of cultural activities: an evaluation of Funnel Beaker societies (4200-2800 cal BC). Journal of Archaeological Science 39: 331-340.

Hiscock, P. (1986). Technological change in the Hunter River valley and the interpretation of late Holocene in Australia. Archaeology in Oceania 21: 40-50.

Hockett, B. (2012). The consequences of Middle Palaeolithic diets on pregnant Neanderthal women. Quaternary International 264: 78-82.

Hockett, B., and Haws, J.A (2003). Nutritional ecology and diachronic trends in Paleolithic diet and health. Evolutionary Anthropology 12: 211-216.

Hockett, B., and Haws, J.A. (2005). Nutritional ecology and the human demography of Neanderthal extinction. Quaternary International 137: 21-34.

Hockett, B., and Haws, J.A. (2009). Continuity in animal resource diversity in the Late Pleistocene human diet of Central Portugal. Before Farming 2009/2: 1-14.

Holdaway, S., and Douglass, M. (2012). A twenty-first century archaeology of stone artifacts. Journal of Archaeological Method and Theory 19: 101-131.

Holdaway, S., Fanning, P., and Shiner, J. (2005). Absence of evidence or evidence of absence? Understanding the chronology of indigenous occupation of New South Wales, Australia. Archaeology in Oceania 40: 33-49.

Hopkinson, T. (2011). The transmission of technological skills in the Palaeolithic: insights from metapopulation ecology. In Roberts, B.W., and Vander Linder, M. (eds.), Investigating Archaeological Cultures: Material Culture, Variability, and Transmission, Springer, Dordrecht, pp. 229-244.

Hopkinson, T., and White, M.J. (2005). The Acheulean and the handaxe. Structure and agency in the Palaeolithic. In Gamble, C. and Porr, M. (eds.), The Hominid Individual in Context: Archaeological Investigations of Lower and Middle Palaeolithic Landscapes, Locales and Artefacts, Routledge, London, pp. $13-28$.

Hopkinson, T., Nowell, A., and White, M. (2013). Life histories, metapopulation ecology, and innovation in the Acheulian. PaleoAnthropology 2013: 61-76.

Hosfield, R. (1999). The Palaeolithic of the Hampshire Basin. A Regional Model of Hominid Behaviour During the Middle Pleistocene. BAR British Series 286, Archeopress, Oxford.

Hosfield, R. (2005). Individuals among palimpsest data. Fluvial landscapes in Southern England. In Gamble, C. and Porr, M. (eds.), The Hominid Individual in Context: Archaeological Investigations of Lower and Middle Palaeolithic Landscapes, Locales and Artefacts, Routledge, London, pp. 220-243. 
Hovers, E., and Belfer-Cohen, A. (2006). "Now you see it, now you don't" - Modern human behaviour in the Middle Paleolithic. In Hovers, E., and Kuhn, S. (eds.), Transitions before the Transition: Evolution and Stability in the Middle Paleolithic and Middle Stone Age, Springer, Dordrecht, pp. 295-304.

Howell, N. (1979). Demography of the Dobe!Kung, Academic Press, New York (NY).

Howells, W.W. (1960). Estimating population numbers through archaeological and skeletal remains. In Heizer, R.F., and Cook, S.F. (eds.), The Application of Quantitative Methods in Archaeology, Quadrangle Books, Chicago (IL), pp. 158-185.

Hublin, J.-J. and, Roebroeks, W. (2009). Ebb and flow or regional extinctions? On the character of Neanderthal occupation of northern environments. Comptes Rendus Palevol 8: 503-509.

Isaac, G.L.L. (1972). Early phases of human behaviour: models in Lower Palaeolithic archaeology, in Clarke, D.L. (ed.), Models in Archaeology, Methuen, London, pp. 167-199.

James, H.V.A., and Petraglia, M. (2005). Modern human origins and the evolution of behaviour in the later Pleistocene of South Africa. Current Anthropology 46: S3-S27.

Jochim, M.A. (1976). Hunter-gatherer Subsistence and Settlement: a Predictive Model, Academic Press, New York (NY).

Johnson, C.N., and Brook, B.W. (2011). Reconstructing the dynamics of ancient human populations from radiocarbon dates: 10000 years of population growth in Australia. Proceedings of the Royal Society B 278: 3748-3754.

Johnson, A.L. (2014). Exploring adaptive variation among hunter-gatherers with Binford's Frames of Reference. Journal of Archaeological Research 22: 1-42.

Jorde, L.B., Rogers, A.R., Bamshad, M., Watkins, W.S., Krakowiak, P., Sung, S., Kere, J., and Harpending, H.C. (1997). Microsatellite diversity and the demographic history of modern humans. Proceedings of the National Academy of Sciences USA 94: 3100-3103.

Kelly, R.L. (1992). Mobility/sedentism: concepts, archaeological measures, and effects. Annual Review of Anthropology 21: 43-66.

Kelly, R.L. (2003). Colonization of new land by hunter-gatherers. Expectations and implications based on ethnographic data. In Rockman, M., and Steele, J. (eds.), Colonization of Unfamiliar Landscapes: The Archaeology of Adaptation, Routledge, London, pp. 44-58.

Kelly, R. L. (2013). The Lifeways of Hunter-Gatherers, Cambridge University Press, Cambridge.

Kelly, R.L., and Todd, L.C. (1988). Coming into the country: early Paleoindian hunting and mobility. American Antiquity 53 (2): 231-244.

Kelly, R.L., Poyer, L., and Tucker, B. (2005). An ethnoarchaeological study of mobility, architectural investment, and food sharing among Madagascar's Mikea. American Anthropologist 107 (3): 403-416.

Kelly, R.L., Surovell, T.A., Shuman, B.N., and Smith, G.M. (2013). A continuous climatic impact on Holocene human population in the Rocky Mountains. Proceedings of the National Academy of Sciences USA 110 (2): 443-447.

Kempe, M., and Mesoudi, A. (2014). An experimental demonstration of the effect of group size on cultural accumulation. Evolution and Human Behaviour (In Press).

Kent, S. (1991). The relationship between mobility strategies and site structure. In Kroll, E.M., and Price, T.D. (eds.), The Interpretation of Archaeological Spatial Patterning, Plenum Press, London, pp. 33-59.

Kent, S. (1992). Studying variability in the archaeological record: an ethnoarchaeological model for distinguishing mobility patterns. American Antiquity 57 (4): 635-660. 
Kent, S., and Vierich, H. (1989). The myth of ecological determinism. Anticipated mobility and site spatial organisation. In Kent, S. (ed.), Farmers as Hunters: The Implications of Sedentism, Cambridge University Press, Cambridge, pp. 96-130.

Klein, R.G., and Cruz-Uribe, K. (1983). Stone age population numbers and average tortoise size at Byneskranskop Cave 1 and Die Kelders Cave 1, Southern Cape Province, South Africa. The South African Archaeological Bulletin 38 (137): 26-30.

Klein, R.G., and Cruz-Uribe, K. (2000). Middle and Later Stone Age large mammal and tortoise remains from Die Kelders Cave 1, Western Cave Province, South Africa. Journal of Human Evolution 38: 169-195.

Klein, R.G., and Steele, T.E. (2013). Archaeological shellfish size and later human evolution in Africa. Proceedings of the National Academy of Sciences USA 110 (27): 10910-10915.

Kline, M.A., and Boyd, R. (2010). Population size predicts technological complexity in Oceania. Proceedings of the Royal Society B 277: 2559-2564.

Kohler, T.A., and Blinman, E. (1987). Solving mixture problems in archaeology: analysis of ceramic materials for dating and demographic reconstruction. Journal of Anthropological Archaeology 6: 1-28.

Kolb, C.C. (1985). Demographic estimates: contributions from ethnoarchaeology on Mesoamerican peasants. Current Anthropology 26 (5): 581-599.

Konigsberg, L.W., and Frankenberg, S.R. (2005). Paleodemography: "Not quite dead". Evolutionary Anthropology 3 (3): 92-105.

Kramer, C. (1980). Estimating prehistoric populations: an ethnoarchaeological approach. In L'Archéologie de l'Iraq. Perspectives et Limites de l'Interpretation Anthropologique des Documents, CNRS, Paris, pp. 315-334.

Kramer, C. (1982). Village Ethnoarchaeology: Rural Iran in Archaeological Perspective, Academic Press, New York (NY).

Kuhn, S.L. (2012). Emergent patterns of creativity and innovation in early technologies. Developments in Quaternary Science 16: 69-87.

Kuijt, I. (2000). People and space in early agricultural villages: exploring daily lives, community size, and architecture in the late Pre-Pottery Neolithic. Journal of Anthropological Archaeology 19: 75-102.

Kuijt, I. (2009). Population, socio-political simplification, and cultural evolution of Levantine Neolithic villages. In Shennan, S (ed.), Pattern and Process in Cultural Evolution, University of California Press, Berkeley (CA), pp. 315-328.

Kuzmin,Y.V. (2009). Comments on Graf, Journal of Archaeological Science 36, 2009 " The Good, the Bad, and the Ugly": evaluating the radiocarbon chronology of the middle and late Upper Palaeolithic in the Enisei River valley, south-central Siberia. Journal of Archaeological Science 36: 2730-2733.

Kuzmin, Y.V., and Keates, S.G. (2005). Dates are not just data: Paleolithic settlement pattern in Siberia derived from radiocarbon record. American Antiquity 70 (4): 773-789.

Lahr, M.M., and Foley, R. (2003). Demography, dispersal and human evolution in the last glacial period. In van Andel, T.H., and Davies, W. (eds.), Neanderthals and Modern Humans in the European Landscape During the Last Glaciation: Archaeological Results of the Stage 3 Project, McDonald Institute Monographs, Cambridge pp. 241-256.

Lalueza-Fox, C., Sampietro, M.L., Caramelli, D., Puder, Y., Lari, M., Calafell, F., Martínez-Maza, C., Bastir, M., Fortea, J., de la Rasilla, M., Bertranpetit, J., and Rosas, A. (2005). Neanderthal evolutionary genetics: mitochondrial DNA data from the Iberian Peninsula. Molecular Biology and Evolution 22 (4): 1077-1081.

Laluza-Fox, C., Rosas, A., Estalrrich, A., Gigli, E., Campos, P.F., García-Tabernero, A., García-Vargas, S., Sánchez- Quinto, F., Ramírez, O., Civit, S., Bastir, M., Huguet, R., Santamaría, D., Gilbert, M.T.P., Willerslev, 
E., and de la Rasilla, M. (2011). Genetic evidence for patrilocal mating behaviour among Neanderthal groups. Proceedings of the National Academy of Sciences USA 108 (1): 250-253.

Langlais, M., Costamagno, S., Laroulandie, V., Pétillon, J.-M., Discamps, E., Mallye, J.-B., Cochard, D., and Kuntz, D. (2012). The evolution of Magdalenian societies in South-West France between 18,000 and 14,000 calBP: Changing environments, changing tool kits. Quaternary International 272-3: 138-149.

Langley, M.C., Clarkson, C., and Ulm, S. (2008). Behavioural complexity in Eurasian Neanderthal populations: a chronological examination of archaeological evidence. Cambridge Archaeological Journal 18 (3): $289-307$.

Langley, M.C., Clarkson, C., and Ulm, S. (2011). From small holes to grand narratives: the impact of taphonomy and sample size on the modernity debate in Australia and New Guinea. Journal of Human Evolution 61 (2): 197-208.

Layton, R., and O'Hara, S. (2010). Human social evolution: a comparision of hunter-gatherer and chimpanzee social organisation. In Dunbar, R., Gamble, C., and Gowlett, J. (eds), Social Brain, Distributed Mind, Proceedings of the British Academy 158, pp. 83-113.

Leakey, M.D. (1975). Cultural patterns in the Olduvai sequence. In Butzer, K.W., and Issac, G. (eds.), After the Australopithecines, Mouton, The Hague, pp. 477-494.

LeBlanc, S. (1971). An addition to Naroll's suggested floor area and settlement population relationship. American Antiquity 36: 210-211.

Lee, R.B. (1976). ! Kung spatial organisation: an ecological and historical perspective. In Lee, R.B., and DeVore, I. (eds.), Kalahari Hunter-Gatherers: Studies of the !Kung San and Their Neighbours, Harvard University Press, Cambridge (MA), pp. 73-97.

Lee, R.B., and DeVore, I. (1968). Man the Hunter, Aldine, New York (NY).

Lenoble, A., Bertran, P., and Lacrampe, F. (2008). Solifluction-induced modifications of archaeological levels: simulation based on experimental data from a modern periglacial slope and application to French Palaeolithic sites. Journal of Archaeological Science 35: 99-110.

Levinson, D. (1979). Population density in cross-cultural perspective. American Ethnologist 6: 742-751.

Longacre, W.A. (1976). Population dynamics at the Grasshopper Pueblo, Arizona. In Zubrow, E.B.W. (ed.), Demographic Anthropology, University of New Mexico Press, Albuquerque (NM), pp. 169-184.

Low B. S. (1990). Human responses to environmental extremeness and uncertainty: a cross-cultural perspective. In Cashdan, E. (ed.), Tribal and Peasant Economies, West View Press, Boulder (CO), pp. 229-255.

Lycett, S.J., and Gowlett, J.A.J. (2008). On questions surrounding the Acheulen 'tradition'. World Archaeology 40 (3): 295-315.

Malthus, T.R. (1872 [1973]). An Essay on the Principle of Population (7 ${ }^{\text {th }}$ edition), J.M. Dent \& Sons Ltd, London.

Marean, C.W., Bar-Matthews, M., Bernatchez, J., Fisher, E., Goldberg, P., Herries, A.I.R., Jacobs, Z., Jerardino, A., Karkanas, P., Minichillo, T., Nilssen, P.J., Thompson, E., Watts, I., and Williams, H.M. (2007). Early human use of marine resources and pigment in South Africa during the Middle Pleistocene. Nature 449: 905908.

Marín-Arroyo, A.B.M. (2009). Economic adaptations during the Late Glacial in northern Spain: a simulation approach. Before Farming 2009/2: 1-18.

Marlowe, F.W. (2005). Hunter-gatherers and human evolution. Evolutionary Anthropology 14: 54-67.

Marsden, P., and West, B. (1992). Population change in Roman London. Britannia 23: 133-140. 
Martin, J.F. (1973). On the estimation of the sizes of local groups in a hunting-gathering environment. American Anthropologist 75 (5): 1448-1468.

Martínez, G., Flensborg, G., and Bayala, P.D. (2013). Chronology and human settlement in northeastern Patagonia (Argentina): Patterns of site destruction, intensity of archaeological signal, and population dynamics. Quaternary International 301: 123-134.

Mauss, M., and Beuchat, H. (1906). Essai sur les variations saisonnières des sociétés Eskimos. L'Année Sociologique 9: 39-132.

McBrearty, S. (2007). Down with the Revolution. In Mellars, P., Boyle, K., Bar-Yosef, O., and Stringer, C. (eds.), Rethinking the Human Revolution, McDonald Institute Monographs, Cambridge, pp. 133-152.

McBrearty, S., and Brooks, A.S. (2000). The revolution that wasn't: a new interpretation of the origin of modern human behaviour. Journal of Human Evolution 39 (5): 453-463.

McNabb, J., Binyon, F., and Hazlewood, L. (2004). The large cutting tools from the South African Acheulean and the question of social traditions. Current Anthropology 45: 653-677.

Meeks S.C., and Anderson D.G. (2012). Evaluating the effect of the Younger Dryas on human population histories in the Southeastern United States. In Eren, M.I (ed.), Hunter-Gatherer Behaviour. Human Response During the Younger Dryas, Left Coast Press, Walnut Creek (CA) pp. 111-138.

Meignen, L., Bar-Yosef, O., Speth, J.D., and Stiner, M.C. (2006). Middle Palaeolithic settlement patterns in the Levant. In Hovers, E., and Kuhn, S.L. (eds.), Transitions before the Transition: Evolution and Stability in the Middle Palaeolithic and Middle Stone Age, Springer, New York (NY) pp. 149-169.

Mellars, P. (1973). The character of the Middle-Upper Palaeolithic transition in Southwestern France. In Renfrew, C. (ed.), The Explanation of Culture Change: Models in Prehistory, Duckworth, London, pp. 255276.

Mellars, P. (1990). The Emergence of Modern Humans, Edinburgh University Press, Edinburgh.

Mellars, P., and French, J.C. (2011). Tenfold population increase in Western Europe at the Neanderthal-tomodern human transition. Science 333: 623-627.

Mellars, P., and French, J.C. (2013). Population changes across the Neanderthal-to-modern-human transition in western France: A reply to Dogandžić and McPherron (2013). Journal of Human Evolution 65 (3): 330-333.

Mellars, P. and Stringer, C. (1989). The Human Revolution: Behavioural and Biological Perspectives on the Origins of Modern Humans, Edinburgh University Press, Edinburgh.

Mellars, P., Boyle, K., Bar-Yosef, O., and Stringer, C. (2007). Rethinking the Human Revolution, McDonald Institute Monographs, Cambridge.

Mesoudi, A., and O'Brien, M. (2009). Placing archaeology within a unified science of cultural evolution. In Shennan, S. (ed.), Pattern and Process in Cultural Evolution, University of California Press, Berkeley (CA), pp. 21-32.

Milisauskas, S. (1972). An analysis of linear culture longhouses at Olszonica B1, Poland. World Archaeology 4 (1): 57-74.

Milner, G.R. (1986). Mississippian period population density in a segment of the central Mississippi river valley. American Antiquity 51 (2): 227-238.

Mithen, S. (1996). The Prehistory of the mind. A Search for the Origins of Art, Religion and Science, Thames and Hudson, London.

Moncel, M.-H., and Rivals, F. (2011). On the question of short-term Neanderthal site occupations. Payre, France (MIS 8-7), and Taubach/Weimar, Germany (MIS 5). Journal of Anthropological Research 67: 47-75. 
Monge, J., and Mann, A. (2007). Paleodemography of extinct hominin populations. In Henke, W., and Tattersall, I. (eds.), Handbook of Paleoanthropology, Springer, Dordrecht, pp.673-700.

Morales, T.M. (1987). An examination of infanticide practices among mobile and sedentary hunter-gatherers. Haliksa; I: UNM Contributions to Anthropology VI: 1-19.

Morin, E. (2004). Late Pleistocene Population Interaction in Western Europe and Modern Human Origins: New Insights Based on the Faunal Remains from Saint-Césaire, Southwestern France, Unpublished PhD thesis, University of Michigan.

Morin, E. (2008). Evidence for declines in human population densities during the early Upper Palaeolithic in western Europe. Proceedings of the National Academy of Sciences USA 105 (1): 48-53.

Munoz, S.E., Gajewski, K., and Peros, M.C. (2010). Synchronous environmental and cultural change in the prehistory of the northeastern United States. Proceedings of the National Academy of Sciences USA 107 (51): 22008-22013.

Munro, N.D., and Atici, L. (2009). Human subsistence change in the Late Pleistocene Mediterranean Basin: the status of research on faunal intensification, diversification and specialisation. Before Farming 2009/1: 1-6.

Naroll, R. (1962). Floor area and settlement population. American Antiquity 27 (4): 587-589.

Neiman, F.D. (1995). Stylistic variation in evolutionary perspective: inferences from decorative diversity and interassemblage distance in Illinois Woodland ceramic assemblages. American Antiquity 60 (1): 7-36.

Neme, G., and Gil, A. (2009). Human occupation and increasing mid-Holocene aridity: southern Andean perspectives. Current Anthropology 50 (1): 149-163.

Neves, A.G.M., and Serva, M. (2012). Extremely rare interbreeding events can explain Neanderthal DNA in living humans. PloS One 7 (10): e47076. doi: 10.1371/journalpone.0047076.

Newell, R.R. (1973). The post-glacial adaptations of the indigenous population of the Northwest European plain. In Kozlowski, S. (ed.), The Mesolithic in Europe, Warsaw University Press, Warsaw, pp. 399-440.

Niekus, M.J.L. (2005/2006). A geographically referenced ${ }^{14} \mathrm{C}$ database for the Mesolithic and the early phase of the Swifterbant culture in the Northern Netherlands. Palaeohistoria 47/48: 41-99.

Nowell, A. (2010). Defining behavioural modernity in the context of Neanderthal and anatomically modern populations. Annual Review of Anthropology 39: 437-452.

Nowell, A., and White, M. (2010). Growing up in the Middle Pleistocene. Life history strategies and their relationship to Acheulian industries. In Nowell, A., and Davidson I (eds.), Stone Tools and the Evolution of Human Cognition, University of Colorado Press, Boulder (CO), pp. 67-81.

O’Brien, M.J., and Lyman, R.L. (2003). Cladistics and Archaeology, University of Utah Press, Salt Lake City (UT).

O’Brien, M.J., and Shennan, S.J. (2010). Issues in anthropological studies of innovation. In O’Brien, M.J., and Shennan, S.J. (eds.), Innovation in Cultural Systems: Contributions from Evolutionary Anthropology, MIT Press, Cambridge (MA), pp. 3-17.

O’Brien, M.J., Darwent, J., and Lyman, R.L. (2001). Cladistics is useful for reconstructing archaeological phylogenies: Palaeoindian points from the southeastern United States. Journal of Archaeological Science 28: $1115-1136$.

O’Brien, M., Boulanger, M.T., Buchanan, B., Collard, M., Lyman, R.L., and Darwent, J. (2014). Innovation and cultural transmission in the American Palaeolithic: phylogenetic analysis of eastern Palaeoindian projectilepoint classes. Journal of Anthropological Archaeology 34: 100-119. 
O’Connell, J.F (1987). Alyawara site structure and its archaeological implications. American Antiquity 52 (1): 74-108.

O'Connell, J.F., and Allen, J. (2007). Pre-LGM Sahul (Pleistocene Australia-New Guinea) and the archaeology of early modern humans. In Mellars, P., Boyle, K., Bar-Yosef, O., and Stringer, C. (eds.), Rethinking the Human Revolution, McDonald Institute Monographs, Cambridge, pp. 395-410.

Odell, G.H. (1980). Towards a behavioural approach to archaeological lithic concentrations. American Antiquity 45 (3): 404-431.

Paine, R. (1997). The need for a multidisciplinary approach to prehistoric demography. In Paine, R.R. (ed.), Integrating Archaeological Demography: Multidisciplinary Approaches to Prehistoric Population, Centre for Archaeological Investigations, Southern Illinois University of Carbonale, Illinois (IL), pp. 1-18.

Pauketat, T.R. (1989). Monitoring Mississippian homestead occupation span and economy using ceramic refuse. American Antiquity 54: 288-310.

Pearson, O.M., Cordero, K.M., and Busby, A.M. (2006). How different were Neanderthal habitual activities? In Harvarti, K., and Harrison, T. (eds.), Neanderthals Revisited: New Approaches and Perspectives, Springer, Dordrecht, pp. 135-156.

Pennington, R. (2001). Hunter-gatherer demography. In Panter-Brick, C., Layton, R.H., and Rowley-Conwy, P. (eds.), Hunter-Gatherers: An Interdisciplinary Perspective, Cambridge University Press, Cambridge, pp. 170204.

Pereira, L., Richards, M., Goios, A., Alonso, A., Albarran, C., Garcia, O., Behar, D.M., Golge M., Hatina, J., Al-Gazali, L., Bradley, D.G., Macauley, V., and Amorim, A. (2005). High-resolution mtDNA Evidence for the Late-Glacial Resettlement of Europe from an Iberian Refuge. Genome Research 15:19-24.

Peros, M.C., Munoz, S.E., Gajewski, K., and Viau, A. (2010). Prehistoric demography of North America inferred from radiocarbon data. Journal of Archaeological Science 37: 656-664.

Perreault, C., and Brantingham, P.J. (2011). Mobility-driven cultural transmission along the forager-collector continuum. Journal of Anthropological Archaeology 30: 62-68.

Petersen, W. (1975). A demographer's view of prehistoric demography (and comments and replies). Current Anthropology 16 (2): 227-245.

Petraglia, M., Clarkson, C., Boivin, N., Haslam, M., Korisettar, R., Chaubey, G., Ditchfield, P., Fuller, D., James, H., Jones, S., Kivisild, T., Koshy, J., Lahr, M.M., Metspalu, M., Roberts, R., and Arnold, L. (2009). Population increase and environmental deterioration correspond with microlithic innovations in South Asia ca. 35,000 years ago. Proceedings of the National Academy of Sciences USA 106 (30): 12261-12266.

Pettitt, P.B. (2000). Neanderthal lifecycles: developmental and social phases in the lives of the last archaics. World Archaeology 31 (3): 351-366.

Pettitt, P.B., and Pike, A.W.G. (2001). Blind in cloud of data: problems with the chronology of Neanderthal extinction and anatomically modern human expansion. Antiquity 75: 415-420.

Pettitt, P.B, and White, M. (2012). The British Palaeolithic. Human Societies at the Edge of the Pleistocene World, Routledge, London.

Pettitt, P.B, Davies, W., Gamble, C.S., and Richards, M.B. (2003). Palaeolithic radiocarbon chronology: quantifying our confidence beyond two half-lives. Journal of Archaeological Science 30: 1685-1693.

Phillips, P. (1972). Population, economy and society in the Chassey-Cortaillod- Lagozza cultures. World Archaeology 4 (1): 41-56.

Pike-Tay, A. (2000). Comment on 'The Tortoise and the Hare. Small Game-Use, the Broad- Spectrum Revolution, and Paleolithic demography’ (Stiner et al. 2000). Current Anthropology 41 (1): 65-66. 
Plog, F. (1975). Demographic studies in Southwestern prehistory. In Swedlund, A.C. (ed.), Population Studies in Archaeology and Biological Anthropology: A Symposium, American Antiquity 40 (2), pp. 94-103.

Porčić , M. (2011). An exercise in archaeological demography: estimating the population size of late Neolithic settlements in the Central Balkans. Documenta Praehistorica XXXVIII: 323-332.

Porčić, M. (2012). Effects of residential mobility on the ratio of average house floor area to average household size: implications for demographic reconstructions in archaeology. Cross-Cultural Research 46 (1): 72 -86.

Postgate, N. (1994). How many Sumerians per hectare? Probing the anatomy of an early city. Cambridge Archaeological Journal 4 (1): 47-65.

Poston Jr., D.L., and Bouvier, L.F. (2010). Population and Society. An Introduction to Demography, Cambridge University Press, Cambridge.

Powell, A., Shennan, S., and Thomas, M.G. (2009). Late Pleistocene demography and the appearance of modern human behaviour. Science 324:1298-1301.

Powell, A., Shennan, S.J., and Thomas, M.G. (2010). Demography and variation in the accumulation of culturally inherited skills. In O'Brien, M.J., and Shennan, S.J. (eds.), Innovation in Cultural Systems: Contributions from Evolutionary Anthropology, MIT Press, Cambridge (MA), pp. 137-160.

Premo, L.S. (2012). Local extinctions, connectedness, and cultural evolution in structured populations. Advances in Complex Systems 15 (1\&2). DOI: 10.1142/S0219525911003268.

Premo, L.S. (2014). Cultural transmission and diversity in time-averaged assemblages. Current Anthropology 55 (1): 105-114.

Premo, L.S., and Kuhn, S.L. (2010). Modeling effects of local extinctions on culture change and diversity in the Paleolithic. PLoS One 5 (12): e15582. doi: 10.1371/journal.pone.0015582.

Prüfer, K., Racimo, F., Patterson, N., Jay, F., Sankararaman, S., Sawyer, S., Heinze, a., Renaud, G., Sudmant, P.H., de Filippo, C., Li, H., Mallick, S., Dannemann, M., Fu, Q., Kircher, M., Kuhlwilm, M. Lachmann, M., Meyer, M., Ongyerth, M., Siebauer, M., Theunert, C., Tandon, A., Moorjani, P., Pickrell, J., Mullikin, J.C., Vohr, S.H., Green, R.E., Hellman, I., Johnson, P.L.F., Blanche, H., Cann, H., Kitzman, J.O., Shendure, J., Eichler, E.E., Lein, E.S., Bakken, T.E., Golovanova, L.V., Doronichev, V.B., Shunkov, M.V., Derevianko, A.P., Viola, B., Slatkin, M., Reich, D., Kelso, J., and Pääbo, S. (2014). The complete genome sequence of a Neanderthal from the Altai Mountains. Nature 505: 43-49.

Ramenofsky, A.F., Neiman, F.D., and Pierce, C.D. (2009). Measuring time, population, and residential mobility from the surface at San Marcos Pueblo, North Central New Mexico. American Antiquity 74 (3): 505-530.

Ramirez-Rossi, F.V., and de Castro, J.M.B. (2004). Surprisingly rapid growth in Neanderthals. Nature 428: 936-939.

Ray, N., Currat, M., and Excoffier, L. (2003). Intra-deme molecular diversity in spatially expanding populations. Molecular Biology and Evolution 20 (1): 76-86.

Read, D. (2006). Tasmanian knowledge and skill: maladaptive imitation or adequate technology? American Antiquity 71 (1): 164-184.

Read, D. (2008). An interaction model for resource implement complexity based on risk and number of annual moves. American Antiquity 73: 599-625.

Read, D. (2012). Population Size Does Not Predict Artifact Complexity: Analysis of Data from Tasmania, Arctic Hunter-Gatherers, and Oceania Fishing Groups. UCLA: Human Complex Systems. Retrieved from: http://escholarship.org/uc/item/61n4303q.

Read, D.W. (1978). Towards a formal theory of population size and area of habitation. Current Anthropology 19 (2): $312-317$. 
Read, D.W., and LeBlanc, S.A. (2003). Population growth, carrying capacity and conflict. Current Anthropology 44 (1): 59-85.

Reed, D.H., O’Grady, J.J., Brook, B.W., Ballou, J.D., and Frankham, R. (2003). Estimates of minimum population sizes for vertebrates and factors influencing those estimates. Biological Conservation 113: 23-34.

Revedin, A., Aranguren, B., Becattini, R., Longo, L., Marconi, E., Lippi, M., Skakun, N., Sinitsyn, A., Spiridonova, E., and Svoboda, J. (2010). Thirty thousand-year-old evidence of plant food processing. Proceedings of the National Academy of Sciences USA 107: 18815-18819.

Richards, M.P., and Trinkaus, E. (2009). Isotopic evidence for the diets of European Neanderthals and early modern humans. Proceedings of the National Academy of Sciences USA 106 (38): 16034-16039.

Richerson, P.J., and Boyd, R. (2008). Response to our critics. Biology \& Philosophy 23 (2): 301-315.

Richerson, P.J., Boyd, R., and Bettinger, R.L. (2009). Cultural innovation and demographic change. Human Biology 81 (2-3): 211-235.

Rick, J.W. (1987). Dates as data: an examination of the Peruvian preceramic radiocarbon record. American Antiquity 52 (1): 55-73.

Riede, F. (2008). The Laacher See-eruption (12,920 BP) and material culture change at the end of the Allerød in Northern Europe. Journal of Archaeological Science 35: 591-599.

Riede, F. (2009). Climate and demography in early prehistory: using calibrated ${ }^{14} \mathrm{C}$ dates as population proxies. Human Biology 81 (2-3):309-337.

Riede, F., and Bentley, R.A. (2008). Increasing the relevance of mathematical model approaches to demographic history. Quality and Quantity 42: 275-281.

Riel-Salvatore, J., and Barton, C.M. (2004). Late Pleistocene technology, economic behaviour and land-use dynamics in Southern Italy. American Antiquity 69 (2): 257-274.

Robson, S.L., and Wood, B. (2008). Hominin life history: reconstruction and evolution. Journal of Anatomy 212 (4): $394-425$.

Rolland, N., and Dibble, H.L. (1990). A new synthesis of Middle Palaeolithic variability. American Antiquity 55: 480-499.

Rosenberg, M. (1994). Pattern, process and hierarchy in the evolution of culture. Journal of Anthropological Archaeology 13: 307-340.

Ross, A. (1985). Archaeological evidence for population change in the middle to late Holocene in southeastern Australia. Archaeology in Oceania 20: 81-89.

Roth, B.J. (2000). Obsidian source characterization and hunter-gatherer mobility: an example from Tucson Basin. Journal of Archaeological Science 27: 305-314.

Sankararaman, S., Mallick, S., Dannemann, M., Prüfer, K., Kelso, J., Pääbo, S., Patterson, N., and Reich, D. (2014). The genomic landscape of Neanderthal ancestry in present-day humans. Nature 2014: doi:10.1038/nature12961

Schacht, R.M. (1981). Estimating past population trends. Annual Review of Anthropology 10: 119-140.

Schacht, R.M. (1984). The contemporaneity problem. American Antiquity 49 (4): 678-695.

Schiffer, M.B. (1975). The effects of occupation span on site content. In Schiffer, M.B., and House, J.H. (eds.), The Cache River Archaeological Project: an Experiment in Contract Archaeology, Arkansas Archaeological Survey Research Series No 8, Fayeetteville, pp. 265-269.

Schiffer, M.B. (1976). Behavioural Archaeology, Academic Press, New York (NY). 
Schiffer, M.B. (1987). Formation Processes of the Archaeological Record, University of New Mexico Press, Albuquerque (NM).

Schmidt, I., Bradtmöler, M., Kehl, M., Pastoors, A., Yafelmaier, Y., Weninger, B., and Weniger, G.-C. (2012). Rapid climate change and variability of settlement patterns in Iberia during the Late Pleistocene. Quaternary International 274: 179-204.

Schott, M.J. (1989). On tool-class use lives and the formation of archaeological assemblages. American Antiquity 54: 9-30.

Schreiber, K.J., and Kintigh, K.W. (1996). A test of the relationship between site size and population. American Antiquity 61 (3): 573-579.

Schrire, C., and Steiger, W.L. (1974). A matter of life and death: an investigation into the practice of female infanticide in the artic. Man 9 (2): 161-184.

Sellet, F. (2006). Two steps forward, one step back: the inference of mobility patterns from stone tools. In Sellet, F., Greaves, R., and Yu, P.-L. (eds.), Archaeology and Ethnoarchaeology of Mobility, University of Florida Press, Gainesville (FL), pp. 221-239.

Shaffer, M.L. (1981). Minimum population sizes for species conservation. BioScience 31 (2): 131-134.

Shennan, S. (1996). From cultural history to cultural evolution. An archaeological perspective on social information transmission. In Wells, J.C.K., Strickland, S., and Laland, K. (eds.), Social Information Transmission and Human Biology, CRC Press, London, pp. 173-189.

Shennan, S. (2000). Population, culture history and the dynamics of culture change. Current Anthropology 41 (5): $811-835$.

Shennan, S. (2001). Demography and cultural innovation: a model and its implications for the emergence of modern human culture. Cambridge Archaeological Journal 11 (1): 5-16.

Shennan, S. (2002). Genes, Memes and Human History. Darwinian Archaeology and Cultural Evolution, Thames and Hudson, London.

Shennan, S. (2006). From cultural history to cultural evolution: an archaeological perspective on social information transmission. In Wells, J.C.K., Strickland, S., and Laland, K. (eds.), Social Information Transmission and Human Biology, Taylor \& Francis, London, pp. 173-190.

Shennan, S. (2008). Evolution in archaeology. Annual Review of Anthropology 37: 75-91.

Shennan, S. (2009a). Pattern and Process in Cultural Evolution, University of California Press, Berkeley (CA).

Shennan, S. (2009b). Evolutionary demography and the population history of the European early Neolithic. Human Biology 81 (2-3): 339-355.

Shennan, S. (2011). Descent with modification and the archaeological record. Philosophical Transactions of the Royal Society B 366: 1070-1079.

Shennan, S. (2012). Darwinian cultural evolution. In Hodder, I. (ed.), Archaeological Theory Today $\left(2^{\text {nd }}\right.$ Edition), Polity Press, Cambridge, pp. 15-36.

Shennan, S. (2013). Demographic continuities and discontinuities in Neolithic Europe: evidence, methods and implications. Journal of Archaeological Method and Theory 20 (2): 300-311.

Shennan, S. and Bentley, R.A. (2008). Style, interaction and demography amongst the earliest farmers of Central Europe. In O’Brien, M.J. (ed.), Cultural Transmission and Archaeology: Issues and Case Studies, Society for American Archaeology Press, Washington (DC), pp. 164-177. 
Shennan, S., and Edinborough, K. (2007). Prehistoric population history: from the late Glacial to the late Neolithic in Central and Northern Europe. Journal of Archaeological Science 34: 1339-1345.

Shennan, S., Downey, S.S., Timpson, A., Edinborough, K., Colledge, S., Kerig, T., Manning, K., and Thomas, M.G. (2013). Regional population collapse followed initial agriculture booms in mid-Holocene Europe. Nature Communications 4 doi:10.1038/ncomms3486.

Smith, E.A. (1983). Anthropological applications of optimal foraging theory: a critical review. Current Anthropology 24 (5): 625-651.

Smith, M.A., and Sharp, N.D. (1993). Pleistocene sites in Australia, New Guinea and Island Melanesia: Geographic and temporal structure of the archaeological record. In Smith, M., Spriggs, M., and Fankhauser, B. (eds.), Sahul in Review: Pleistocene Archaeology in Australia, New Guinea and Island Melanesia, Occasional Papers in Prehistory 24, Australian National University, Canberra, pp. 37-59.

Smith, P.E.L. (1966). Le Solutréen en France. Delmas, Bordeaux.

Smith, P.E.L. (1972). Changes in population pressure in archaeological explanation. World Archaeology 4: 518 .

Smith, S., Hughes, J., and Mithen, S. (2009). Explaining global patterns in Lower Palaeolithic technology. Simulations of hominin dispersals and cultural transmission using stepping out. In Shennan, S. (ed.), Pattern and Process in Cultural Evolution, University of California Press, Berkley (CA), pp. 175-190.

Smith, T.M., Tafforeau, P., Reid, D.J., Pouech, J., Lazzari, V., Zermeno, J.P., Guatelli-Steinberg, D., Oleiniczak, A.J., Hoffman, A., Radovčić, J., Makaremi, M., Toussaint, M., Stringer, C., and Hublin, J.-J. (2010). Dental evidence for ontogenetic differences between modern humans and Neanderthals. Proceedings of the National Academy of Sciences USA 107 (49): 20923-20928.

Sørensen, B. (2011). Demography and the extinction of the European Neanderthals. Journal of Anthropological Archaeology 30: 17-29.

Sorensen, M.V., and Leonard, W.R. (2001). Neanderthal energetic and foraging efficiency. Journal of Human Evolution 40: 483-495.

Stajich, J.E., and Hahn, M.W. (2005). Disentangling the effects of demography and selection in human history. Molecular Biology and Evolution 22(1): 63-73.

Steele, J. (1996). On predicting hominid group sizes. In Steele, J., and Shennan, S. (eds.), The Archaeology of Human Ancestry: Power, Sex and Tradition, Routledge, London pp. 230-252.

Steele, J., and Shennan, S. (2009). Introduction: Demography and cultural macro evolution. Human Biology 81(2-3): 105-119.

Stiner, M.C. (2001). Thirty years on the "Broad Spectrum Revolution" and Palaeolithic demography. Proceedings of the National Academy of Sciences USA 98 (13): 6993-6996.

Stiner, M.C. (2009). Prey choice, site occupation intensity and economic diversity in the Middle-early Upper Palaeolithic at the Üçağizli Caves, Turkey. Before Farming 2009/3: 1-20.

Stiner, M.C., and Munro, N.D. (2002). Approaches to prehistoric diet breadth, demography, and prey ranking systems in time and space. Journal of Archaeological Method and Theory 9 (2): 181-214.

Stiner, M.C., Munro, N.D., Surovell, T.A., Tchernov, E., and Bar-Yosef, O. (1999). Palaeolithic population growth pulses evidenced by small animal exploitation. Science 283: 190-194.

Stiner, M.C., Munro, N.D., and Surovell, T.A. (2000). The tortoise and the hare: small game use, the broad spectrum revolution and palaeolithic demography. Current Anthropology 41 (1): 39-73. 
Stiner, M.C., Beaver, J.E., Munro, N.D., and Surovell, T.A. (2008). Modeling palaeolithic predator-prey dynamics and the effects of hunting pressure on prey 'choice'. In Bocquet-Appel, J.-P (ed.), Recent Advances in Palaeodemography: Data, Techniques, Patterns, Springer, Dordrecht, pp. 143-178.

Storey, G.R. (1997). The population of ancient Rome. Antiquity 71: 966-978.

Straus, L.G. (2011). Were there human responses to Younger Dryas in Cantabrian Spain? Quaternary International 242: 328-335.

Straus, L.G., Altuna, G., Clark, G.A., Gonzalez Morales, M., Laville, H., Leroi-Gourhan, A., Menendez de la Hoz, M., and Ortea, J.A. (1981). Paleoecology at La Riera (Asturias, Spain). Current Anthropology 22: 655682.

Straus, L.G., Bicho, N., and Winegardner, A.C. (2000). The Upper Palaeolithic settlement of Iberia: firstgeneration maps. Antiquity 74: 553-566.

Stringer, C., and Gamble, C. (1993). In Search of the Neanderthals. Solving the Puzzle of Human Origins, Thames and Hudson, London.

Sullivan, A.P. (1992). Investigating the archaeological consequences of short-duration occupation. American Antiquity 57 (1): 99-115.

Sumner, W.M. (1979). Estimating population by analogy: an example. In Kramer, C. (ed.), Ethnoarchaeology: Implications of Ethnography for Archaeology, Columbia University Press, New York (NY), pp. 164-174.

Surovell, T.A. (2000). Early Paleoindian women, children, mobility and fertility. American Antiquity 65 (3): 493-508.

Surovell, T.A. (2009). Toward a Behavioural Ecology of Lithic Technology. Cases From Paleoindian Archaeology, University of Arizona Press, Tuscon (AZ).

Surovell, T.A., and Brantingham, P.J. (2007). A note on the use of temporal frequency distributions in studies of prehistoric demography. Journal of Archaeological Science 34: 1868-1877.

Surovell, T.A., Finley, J.B., Smith, G.M., Brantingham, P.J., and Kelly, R. (2009). Correcting temporal frequency distributions for taphonomic bias. Journal of Archaeological Science 36 (8): 1715-1724.

Tallavaara, M., and Seppä, H. (2011). Did the mid-Holocene environmental changes cause the boom and bust of hunter-gatherer population size in eastern Fennoscandia? The Holocene 22 (2): 215-225.

Tallavaara, M., Pesonen, P., and Oinonen, M. (2010). Prehistoric population history in eastern Fennoscandia. Journal of Archaeological Science 37: 251-260.

Thacker, P.T. (2006). Local raw material exploitation and prehistoric hunter-gatherer mobility. In Sellet, F., Greaves, R., and Yu, P.-L. (eds.), Archaeology and Ethnoarchaeology of Mobility, University of Florida Press, Gainesville (FL), pp. 240-261.

Thompson, J.E.S. (1971). Estimates of Maya population: deranging factors. American Antiquity 36 (2): 214 216.

Trinkaus, E. (1995). Neanderthal mortality patterns. Journal of Archaeological Science 22: 121-142.

Trinkaus, E. (2012). Neanderthals, early modern humans and rodeo riders. Journal of Archaeological Science 39 (12): 3691-3693.

Turnbull, C.M. (1972). Demography of small scale societies. In Harrison, G.A., and Boyce, A.J. (eds.), The Structure of Human Populations, Clarendon Press, Oxford, pp. 283-312.

Vaesen, K. (2013). Cumulative cultural evolution and demography. PloS One 7(7): e40989. doi:10.1371/journal.pone.0040989. 
van Andel, T.H., Davies, W., and Weniger, B. (2003). The human presence in Europe during the last glacial period 1: human migrations and the changing climate. In van Andel, T.H., and Davies, W. (eds.), Neanderthals and Modern Humans in the European Landscape During the Last Glaciation: Archaeological Results of the Stage 3 Project, McDonald Institute Monographs, Cambridge, pp. 31-57.

Varien, M.D., and Mills, B.J. (1997). Accumulations research: problems and prospects for estimating site occupation span. Journal of Archaeological Method and Theory 4 (2): 141-191.

Varien, M.D., and Ortman, S.G. (2005). Accumulations research in the Southwest United States: middle-range theory for big-picture problems. World Archaeology 37 (1): 132-155.

Varien, M.D., and Potter, J.M. (1997). Unpacking the discard equation: the accumulation of artefacts in the archaeological record. American Antiquity 62 (2): 194-213.

Vegari, C., and Foley, R.A. (2014). High selection pressure promotes increase in cumulative adaptive culture. PloS One 9 (1): e86406. doi: 10.11371/journal.pone.0086406.

Villa, P., and Roebroeks, W. (2014). Neanderthal demise: an archaeological analysis of the modern human superiority complex. PloS One 9 (4): e96424. doi:10.1371/journal.pone.0096424.

Wadley, L. (1987). Later Stone Age Hunters and Gatherers of the Southern Transvaal. Social and Ecological Interpretation, BAR International Series 380, Archaeopress, Oxford.

Wall, J.D., Yang, M.A., Jay, F., Kim, S.K., Durand, E.Y., Stevison, L.S., Gignoux, G., Woerner, A., Hammer, M.F., and Slatkin, M. (2013). Higher levels of Neanderthal ancestry in East Asians than in Europeans. Genetics 194 (1): 199-209.

Weeks, J.R. (1999). Population. An Introduction to Concepts and Issues (7 ${ }^{\text {th }}$ Edition), Wadsworth, Belmont (CA).

Welinder, S. (1979). Prehistoric Demography, Acta Archaeologica Lundensia Series in Archaeology 8, CWK Gleerup, Lund.

Wheat, J.B. (1972). The Olson-Chubbock Site: A Palaeoindian Bison Kill. Memoirs of the Society of American Archaeology 26.

White, R. (1982). Rethinking the Middle/ Upper Paleolithic transition. Current Anthropology 23: 169-192.

White, R. (1985). Upper Palaeolithic Land-use in the Périgord. A Topographic Approach to Subsistence and Settlement, BAR International Series 253, Archeopress, Oxford.

White, T.D., Asfaw, B., DeGusta, D., Gilbert, H., Richards, G.D., Suwa, G., and Clark Howell, F. (2003). Pleistocene Homo Sapiens from Middle Awash, Ethiopia. Nature 423: 742-747.

White, T.E. (1953). A method of calculating the dietary percentage of various food animals utilised by Aboriginal peoples. American Antiquity 18: 393-399.

Whitelaw, T. (1983). People and space in hunter-gatherer camps: A generalising approach in ethnoarchaeology. Archaeological Review from Cambridge 2: 2: 48-66.

Whitelaw, T. (1991). Some dimensions of variability in the organisation of community space among foragers. In Gamble, C.S., and Boismier, W.A. (eds.), Ethnoarchaeological Approaches to Mobile Campsites, International Monographs in Prehistory, Ann Arbour (MI), pp. 139-188.

Wicks, K., and Mithen, S. (2014). The impact of the abrupt 8.2 ka cold event on the Mesolithic population of western Scotland: a Bayesian chronological analysis using 'activity events' as a population proxy. Journal of Archaeological Science 45: 250-269.

Wiessner, P. (1974). A functional estimator of population from floor area. American Antiquity 39 (2): 343-350. 
Williams, A.N. (2012). The use of summed radiocarbon probability distributions in archaeology: a review of methods. Journal of Archaeological Science 39: 578-589.

Williams, A.N. (2013). A new population curve for prehistoric Australia. Proceedings of the Royal Society B 280, 1-9.

Williams, A.N., Ulm, S., Goodwin, I.D., and Smith, M. (2010). Hunter-gatherer response to late Holocene climatic variability in northern and central Australia. Journal of Quaternary Science 25 (6): 831-838.

Wilmsen, E.N. (1973). Interaction, spacing behavior, and the organization of hunting bands. Journal of Anthropological Research 29 (1): 1-31.

Winterhalder, B., and Smith, E.A. (2000). Analysing adaptive strategies: Human Behavioural Ecology at twenty-five. Evolutionary Anthropology 9 (2): 51-72.

Wobst, H.M. (1974). Boundary conditions for Palaeolithic social systems: a simulation approach. American Antiquity 39: 147-178.

Wobst, H.M. (1976). Locational relationships in Paleolithic society. Journal of Human Evolution 5: 49-58.

Wobst, H.M. (1978). The archaeo-ethnology of hunter-gatherers or the tyranny of the ethnographic record in archaeology. American Antiquity 2: 303-309.

Woodbridge, J., Fyfe, R.M., Roberts, N., Downey, S., Edinborough, K., and Shennan, S. (2012). The impact of the Neolithic agricultural transition in Britain: a comparison of pollen-based land-cover and archaeological ${ }^{14} \mathrm{C}$ date-inferred population change. Journal of Archaeological Science (in press)

http://dx.doi.org/10.1016/j.jas.2012.10.025.

Wylie, A. (1985). The reaction against analogy. Advances in Archaeological Method and Theory 8: 63-111.

Wynne, T., and Coolidge, F.L. (2004). The expert Neanderthal mind. Journal of Human Evolution 46 (4): $467-$ 487.

Yellen, J.E. (1977). Archaeological Approaches to The Present. Models For Reconstructing The Past, Academic Press, New York (NY).

Yengoyon, A.A. (1972). Biological and demographic components in aboriginal Australian socio-economic organisation. Oceania 43 (2): 85-95.

Zilhão, J. (2007). The emergences of ornaments and art: an archaeological perspective on the origins of "behavioural modernity”. Journal of Archaeological Research 15: 1-54.

Zilhão, J., Angelucci, D.E., Badal-Garcia, E., d'Errico, F., Daniel, F., Dayet, L., Douka, K., Higham, T.F.G., Martinez-Sánchez, M.J., Montes-Bernárdez, R., Murcia-Mascarós, S., Pérez-Sirvent, C., Roldán-Garcia, C., Vanhaeren, M., Villaverde, V., Wood, R., and Zapata, J. (2010). Symbolic use of marine shells and mineral pigments by Iberian Neandertals. Proceedings of the National Academy of Sciences USA 107 (3): 1023-1028.

Zubrow, E.B.W. (1971). Carrying capacity and dynamic equilibrium in the prehistoric Southwest. American Antiquity 36 (2): 127-138.

Zubrow, E.B.W. (1975). Prehistoric Carrying Capacity: A Model, Cummings Publishing Company, Memlo Park (CL).

Zubrow, E.B.W. (1989). The demographic modelling of Neanderthal extinction. In Mellars, P., and Stringer, C. (eds.), The Human Revolution, Edinburgh University Press, Edinburgh, pp. 212-231. 
